This is a postprint (final submitted manuscript) version of the following article:

Moulick, A. G., Alexiou, K., Dowin Kennedy, E. D., \& Parris, D. L. (2020). A total eclipse of the heart: compensation strategies in entrepreneurial nonprofits. Journal of Business Venturing, https://doi.org/10.1016/j.jbusvent.2019.105950.

Per publisher policy, this postprint is licensed with a Creative Commons AttributionNonCommercial-NoDerivatives 4.0 International license (CC BY-NC-ND) license. 
A Total Eclipse of the Heart: Compensation Strategies in Entrepreneurial Nonprofits

\begin{abstract}
We examine how shifting resource dependencies influence compensation strategy during commercial transitions within entrepreneurial nonprofits. Longitudinal sample of 4,732 cultural nonprofits from the United States, show compensation strategies reflective of contributed resource dependence shift non-linearly as nonprofits transition to market-based resource dependence. Dynamic quadratic models unveil a dual threshold of commercialization concerning this transition. Nonprofits at moderate stage of commercialization, contend with competing resource dependencies from both contributed and market-based sources, resulting in a decrease in their compensation and an increase in part-time employment. At higher stages, contributed resource dependence is eclipsed by market-based dependence, reflected in nonprofit compensation strategies.
\end{abstract}

\title{
1. Executive Summary
}

Social entrepreneurship occurs when organizations blend the creation of social value with market-based revenue generation. One important category of social entrepreneurship relates to entrepreneurial non-profit organizations (NPOs), which fall along a continuum of commercialization dependent on the percentage of their revenue that is generated from marketbased sources. An important research stream has begun to examine how commercialization affects NPO strategy and outcomes (Gras and Mendoza-Abarca, 2014; Nason et al., 2018). This research extends that stream by examining the effect of commercialization on compensation strategy.

The commercialization of NPOs is a hotly debated topic in research and policy. While some tout the benefits of commercialization include greater autonomy, financial stability, and flexibility (Kim, 2016; Klein et al., 2013; Salamon, 2001b), others argue that it threatens an NPOs legitimacy, fundraising, and survival (Brown, 2018; Gras and Mendoza-Abarca, 2014; Nason et al., 2018; Smith et al., 2012). Employees play a fundamental role in the success of NPOs, particularly as they undergo the structural transitions required for commercialization. Compensation strategy serves as an important tool both to attract and retain employees as well as a signal to external stakeholders. 
This paper draws on Resource Dependence Theory (RDT) (Pfeffer and Salancik, 1978) to show how commercialization fundamentally alters the resource dependencies within NPOs. As entrepreneurial NPOs commercialize, they transition through three stages: a dependence on resources that are contributed by external stakeholders; a dependence on resources earned through market-based activities; and a transitional stage between the two where both dependencies are present. We argue that this transition requires NPOs perform internal resource calculations to balance claims from their dominant stakeholders-nonprofit funders and overseers at low levels of commercialization, employees at high levels of commercialization, and both groups at moderate levels of commercialization - when developing compensation strategies.

We test our hypotheses with longitudinal financial, programmatic, and operational data from 4,732 registered 501(c)3 of arts and cultural NPOs in the U.S. We utilize dynamic Generalized Least Squares regression models to test our hypotheses and find non-linear relationships between commercialization and NPOs' compensation strategy as well as identify two important thresholds of commercialization. NPOs initially depress compensation as they increase commercial activity, relying heavily on their employees' willingness to donate labor at belowmarket wages, effectively exploiting their commitment to mission. This effect is most pronounced when NPOs are equally dependent on contributed and market-based resources. Once commercialization reaches the point that NPOs are no longer beholden to their sources of contributed revenue, they improve compensation conditions in order to retain the talent necessary to maintain their market-based sources of revenue and expand their investments in programmatic roles.

The goal of this research is to build upon an ongoing conversation regarding the effects of pursuing an increasing proportion of market-based revenue - relative to total revenue - within 
entrepreneurial NPOs. We find that entrepreneurial NPOs shift their compensation strategies as they transition from contributed resource dependency to market-based resource dependency in ways that do not transfer benefit to their employees in a linear manner. These results build upon existing research by examining resource dependence in a dynamic setting, revealing a nuanced picture of how commercialization affects NPO compensation strategy as organizations grapple with shifting dependencies and the pressure these dependencies exert on compensation, for the better and for the worse.

\section{Introduction}

Nonprofit organizations (NPOs) are increasingly practicing a form of social entrepreneurship by pursuing market-based revenue from the sales of goods and services, much like businesses (Gras and Mendoza-Abarca, 2014; Moss et al., 2011). It is widely believed that market-based revenue is beneficial for NPOs due to increasing competition and declining philanthropic giving (Lyons and Kickul, 2013). Positive effects of NPOs pursuing market-based revenue include: improved flexibility (Kim, 2017), financial independence (Salamon, 2001a), and enhanced organizational capabilities (Klein et al., 2013). Indeed, the field of social entrepreneurship assumes - implicitly or explicitly - that a hybrid model combining the pursuit of market-based revenue with a central social purpose is superior to the inefficient model of the charitable nonprofit.

Nonetheless, where there are opportunities there are threats. As NPOs behave more like businesses, they are exposed to increased scrutiny over their management practices, particularly relating to compensation. Overdependence on market-based revenue can jeopardize survival in entrepreneurial NPOs (Gras and Mendoza-Abarca, 2014), and the inherent risk associated with any entrepreneurial venture is heightened because the marketization of traditionally nonmarket 
spheres is contentious (Brown, 2018; Eikenberry and Kluver, 2004). Straying too far from the institutional norms ascribed to the nonprofit sector by behaving "too much like a business" may further threaten an NPO's legitimacy and make resource acquisition more difficult (Dees, 1998; Smith et al., 2012). In order to develop a more nuanced understanding of the costs and benefits of NPOs pursuing increasing proportions of market-based revenue relative to total revenue (which we refer to as commercialization), we need to examine the effects of these actions on specific organizational outcomes.

Our study contributes to this broader conversation by examining one such outcome: the compensation strategies of entrepreneurial NPOs. Compensation practices - because of their visibility and the strong norms ascribed to the sector - are often the first characteristic to come under scrutiny as NPOs pursue market-based revenue. The nonprofit sector in the US has seen $25 \%$ growth of new organizations in the past decade, making it the third largest workforce behind retail and manufacturing (Salamon, 2018). The sector accounted for approximately 12.3 million jobs in 2016, or roughly 10.2 percent of total U.S. private sector employment (Bureau of Labor Statistics, 2018). As such, the primary purpose of the study is to address the question: how does commercialization within NPOs affect compensation strategy?

To address this question, we draw on resource dependence theory (Pfeffer and Salancik, 1978) coupled with related research examining the outcomes of commercialization within entrepreneurial NPOs (e.g.Gras and Mendoza-Abarca, 2014) to inform our argument. We posit that as they become increasingly commercialized, NPO's resource dependencies fundamentally shift from traditional sources of contributed revenue (contributed revenue dependence) to a dependence on market-based revenue (market-based resource dependence). Using a longitudinal sample of 4,732 U.S. cultural nonprofits, we show that compensation strategies reflective of 
contributed resource dependence shift non-linearly as NPOs transition to market-based resource dependence. In addition, we uncover a dual threshold concerning this transition.

Our analyses reveal nuanced empirical insights by operationalizing compensation strategies in terms of salary, job roles, and workforce composition (full time vs. part-time employees). We contribute to the related literature in three distinct ways. First, we identify two thresholds of commercialization where compensation strategy shifts, indicating the level of commercialization at which ex-post market-based resource dependencies eventually come to eclipse ex-ante contributed resource dependencies - and the expectations they contain - to reward entrepreneurial talent in highly commercialized NPOs. Second, we add to the underdeveloped research area of compensation strategies in entrepreneurial contexts (Manne, 2011), specifically uncovering how NPOs strategically shift workforce composition to respond to shifting resource dependencies. Third, we show that NPOs exploit donative labor from their employees to manage dual resource dependence. In doing so, we reveal a detailed picture of how shifting resource dependencies are managed during commercial transition.

The remainder of this manuscript is organized as follows. First, we review relevant research to set the stage for our theoretical framework in section three. Drawing on insights from resource dependence theory, in section four we develop a series of hypotheses predicting the effects of commercialization on different dimensions of NPO compensation strategy. We then discuss our empirical methods in section five and report the results of our analyses in section six. We conclude with a discussion of the implications for practitioners, limitations of our study, and suggestions for future research in section seven.

\section{Literature Review}

\subsection{Entrepreneurship in Nonprofit Contexts}

Financial capital represents perhaps the most critical of resources for NPOs. In general, 
NPOs acquire capital either through contributed sources, such as government grants, foundations, and donations or through market-based sources, such as the sale of products/services (Salamon, 1999). Traditionally, NPOs do not generate a significant portion of revenue through the sale of products/services, relying instead on contributed revenue (Fitzgerald and Shepherd, 2018). NPOs have been encouraged to diversify their revenue streams by adding independent business units (Froelich, 1999) due to several factors: pressure from external stakeholders to maintain low overhead (Bowman, 2006; Lecy and Searing, 2014), responding to a severe cost-revenue squeeze (Gregory and Howard, 2009; Nielson, 1986), and increasing competition (Kim, 2017). NPOs are said to be entrepreneurial when they "sense, select, and shape opportunities" (Abdelgawad et al., 2013: 394) to access new markets and generate more revenue from market-based sources (Gras and Mendoza-Abarca, 2014; Hitt et al., 2011; Ireland et al., 2003). We refer to the process of increasing the relative proportion of total revenue that comes from market-based sources in NPOs as commercialization. NPOs can be placed along a commercialization continuum (Figure 1) from being wholly dependent on contributed sources to being wholly dependent on market-based sources of revenue.

[Insert Figure 1 about here]

NPOs relying heavily on their contributed sources of funding (those with low levels of commercialization) often find themselves in situations where external stakeholders have significant power over the organization, and a substantial body of literature has documented the expectations and restrictions these funders place on NPOs (e.g., Bowman, 2006; Lecy and Searing, 2014). Conversely, research shows that commercialization can enable NPOs to become more flexible, autonomous and financially independent (Kim, 2017; Salamon, 2001a), in addition to improving their organizational capabilities (Klein et al., 2013) and decreasing their 
financial vulnerability (Carroll and Stater, 2008; Keating et al., 2005). Revenue diversification by NPOs' reduces dependence on a handful of traditional NPO funders like governments and donors (Dees, 2007; Leroux, 2006) while also subverting increased competition for donative dollars and dire consequences of shrinking philanthropic support (Lyons and Kickul, 2013). Furthermore, commercialization provides NPOs the latitude to innovate within their missionrelated programs and to be bold in their strategic decisions (Parris et al., 2018).

Despite the potential benefits of pursuing commercial revenue, NPOs engaging in these strategies face significant challenges and risks. First, NPO leaders often lack the managerial skills necessary for successful launch and management of commercial programs (Dees, 2012). Second, market-based revenue can depress individual donations to NPOs, especially if donors perceive such a strategy to be out of alignment with the organizational mission and/or incompetently managed (Smith et al., 2012). Third, mission drift and legitimacy threats present significant challenges that an NPO must successfully navigate as they commercialize (Fitzgerald and Shepherd, 2018; Nason et al., 2018; Pache and Santos, 2013). Finally, commercialization may directly impact NPO survival as shown by Gras and Mendoza-Abarca (2014) who found that entrepreneurial NPOs who become too dependent on market-based revenue are at an increased risk of failure.

Since NPOs have historically had low levels of market-based revenue, funders have been the dominant stakeholders serving as gatekeepers of critical resources (Mitchell et al., 1997). Funders have institutionalized expectations of how NPOs should act in order to receive funding that constrain NPO behavior. At its heart, a shift towards market-based revenue is an attempt for NPOs to strategically restructure their relationship with funders and more effectively balance the power exerted by these stakeholders. As entrepreneurial NPOs integrate market-based revenue 
programs they must successfully adopt a blend of practices from both the commercial and nonprofit sectors (Pache and Santos, 2013). Failure to effectively navigate expectations from both sectors can undermine the legitimacy of mission driven organizations and their ability to attract adequate resources, ultimately diminishing their chance of survival (Battilana and Dorado, 2010; Battilana and Lee, 2014).

Distinct from the practices of for-profit organizations, if entrepreneurial NPOs capture enough market-based revenue to generate a profit the surplus must be reinvested back into the organization (Hansmann, 1981). This is a critical difference between nonprofit and for-profit entrepreneurship, as the legal non-distribution tax constraint in the nonprofit sector prevents founder(s), board members, and executives from appropriating organizational surplus. Extant research has yet to examine the extent to which market-based revenue in NPOs is reinvested in the most important of operational resources—human capital—via more competitive compensation strategies in NPOs. Next, we review the literature on compensation strategy relevant to the nonprofit context.

\subsection{Compensation Strategy in Nonprofit Contexts}

Compensation strategies include how much an organization spends on salary, fringe benefits, job role-based spending, and part-time versus full-time employment (Gomez-Mejia and Balkin, 1992; Milkovich and Newman, 2008). Compensation strategies act as a signaling device that reflect organizational values, reinforce organizational culture, and influence employees' willingness to join the organization and their likelihood of retention (Cyert and March, 1963). Employees play a critical role in achieving the pro-social goals in organizations since they are the conduits as well as stakeholders in these initiatives (Battilana and Dorado, 2010; Margolis and Walsh, 2003; Risi and Wickert, 2016). When organizations combine purpose and profit, 
buy-in from employees is essential, as employees are either a source of resistance or instigators of positive change (Wickert and de Bakker, 2018). The inclination for employees to make firm specific investments, such as leading organizational improvements (Hoskisson et al., 2018), creating positive organizational change (Wickert and de Bakker, 2018), increasing innovation (Corbett, 2018), and social impact (Hart et al., 2015) is influenced by compensation practices. Therefore, compensation expenditures are often an organization's largest operating cost, accounting for " $10-50$ percent of total operating costs and as much as 90 percent in service or knowledge intensive organizations" (Gomez-Mejia and Balkin, 1992: 18).

Despite its importance, compensation strategy within NPOs remains poorly understood. While employing roughly ten percent of the US workforce, NPOs have earned a reputation for paying submarket wages. Traditionally, the philanthropic funders have rewarded specific policies and actions that promote social welfare over paying market wages and expect a level of sacrifice from NPO employees (Dempsey and Sanders, 2010; Oster, 1995). Preston (1989) found nonprofit employees made $20 \%$ less than for-profit employees in similar roles, and when including fringe benefits, this cost differential increased to $40 \%$ (Emanuele, 1997). Some have explained the compensation differential by the willingness of employees to "donate" labor in the nonprofit sector, either through accepting sub-market wages (Rose-Ackerman, 1996) or donating their time beyond the hours they are compensated (Knutsen and Chan, 2014).

NPOs with low levels of commercialization require fundraisers and managers who can successfully attract revenue from funders; whereas, NPOs with high levels of commercialization require employees with the skill sets necessary to attract revenue from the market, often meaning that NPOs have to recruit employees from the for-profit sector. As a result, entrepreneurial NPOs must effectively manage compensation strategies to attract and retain entrepreneurial talent while 
simultaneously adhering to the more traditional expectations their dominant stakeholders have regarding expenses and compensation (Battilana and Dorado, 2010).

Our review highlights two important insights for entrepreneurial NPOs. First, despite the espoused benefits of increasing the proportion of their total revenue from market-based sources, NPOs face significant challenges and risks in so doing. These risks are particularly salient with respect to NPOs' most dominant stakeholders and their dependence on those gatekeepers of critical resources. Second, entrenched in the nonprofit sector is a history of exploitative compensation, where paying submarket wages has become institutionalized and taken for granted. Together, these arguments paint a troubling picture for NPOs seeking entrepreneurial opportunities in terms of both compensation and managing critical resource dependencies. In order to better understand the dynamics of these shifting dependencies and the effects of commercialization on nonprofit compensation strategies, we next turn our attention to resource dependence theory (RDT) to inform our hypotheses.

\section{Theory and Hypotheses}

RDT offers valuable insights for both entrepreneurship in the NPO context (Gras and Mendoza-Abarca, 2014) and compensation strategy in organizations (Gomez-Mejia and Balkin, 1992; Pfeffer and Davis-Blake, 1987). According to RDT, the survival of an organization is dependent on its ability to manage an unpredictable external environment in order to secure a stable flow of resources (Pfeffer and Salancik, 1978). The focal organization is constrained by actors in their external environment and "become interdependent with those elements of the environment with which they transact" (Pfeffer, 1982: 192-193). The two primary dimensions of the dependence that focal organizations experience are mutual dependence — the sum of bilateral dependencies experienced and power imbalance- when external actors wield more power over 
resource relationships. The RDT perspective posits the interplay of these two dimensions drives organizational strategies (Casciaro and Pirskorki, 2005).

For entrepreneurial NPOs in particular, as the level of commercialization increases dependence on contributed sources of revenue decreases, fundamentally shifting the power balance between the NPO and its funders (Gras and Mendoza-Abarca, 2014). At the same time, as commercialization increases, so too does dependence on employees with skillsets related to capturing market-based revenue. According to RDT, these shifting dependencies as a will have direct implications for compensation strategy (Pfeffer and Davis-Blake, 1987). However, extant theory fails to provide a clear framework for predicting how exactly commercialization influences compensation strategy as NPOs transition from contributed resource dependence to market-based resource dependence. Accordingly, in the sections to follow, we deduce a set of hypotheses by extending RDT in this unique context of shifting resource dependency. We have included Table 1 at the end of this section to summarize the theoretical arguments outlined for each of our hypotheses.

\subsection{Contributed vs. Market-based Resource Dependence and Compensation}

RDT predicts that the survival of traditional NPOs is predicated upon their ability to secure a continuous flow of capital from the contributed sources. Accordingly, the gatekeepers of these resources represent the most influential external stakeholders to whom the organization is ultimately accountable (Mitchell et al., 1997). Resources derived from these stakeholders extend beyond their financial contributions to NPOs, as relationships with these stakeholders confer legitimacy, and government agencies grant NPOs the ability to receive tax deductible contributions (Salamon, 2001a, 2018). From the perspective of NPOs, key funders such as corporate donors, private donors, and/or government agencies can easily shift their support to 
similar nonprofits (Gras and Mendoza-Abarca, 2014; Gronbjerg, 1991). Thus, NPOs with significant contributed resource dependence (situated at the lower end of the commercialization continuum) are power disadvantaged and will experience serious social control of their strategic choices from various nonprofit stakeholders.

Consequently, a shift towards commercialization is often an attempt by NPOs to unilaterally restructure the power dynamic with dominant stakeholders (Gras and Mendoza-Abarca, 2014). Employees are an important organizational resource and part of internal resource calculus for unilateral restructuring (Gomez-Mejia and Balkin, 1992; Pfeffer, 1982). Donors and funders emphasize maximum resource allocation to NPOs' core mission, exerting external pressure to keep overhead expenses low (Bowman, 2006; Lecy and Searing, 2014). Compensation spending drives up NPOs' overhead expenses and is easily observable to stakeholders, through internal reports and publicly available tax returns (Benzing et al., 2011; Chikoto and Neely, 2014). Often NPOs will conform to institutional expectations of 'donative labor' (i.e., paying below market wages) to maintain legitimacy (King and Lewis, 2017). Furthermore, NPO employees tend to value social impact over financial success and widely demonstrate a willingness to sacrifice higher pay (Dees, 2012). In this regard, employees and the organization engage in a mutually dependent relationship that is rooted in shared goals and values. If NPOs pay excessively, they may stress their contributed resource dependence and, in extreme cases, jeopardize their taxexempt status (Nonprofits, 2018). Therefore, NPOs exposed to contributed resource dependence will experience downward pressure on their compensation spending.

However, entrepreneurial NPOs shifting from contributed resource dependence to marketbased resource dependence often experience dual resource dependence - where they are reliant on attracting resources from both contributed and market-based sources at roughly similar levels. 
In this stage of commercialization, entrepreneurial NPOs are beholden to expectations from both sectors. The pressure to utilize compensation strategy as a signal of conformity is especially strong when NPOs are experiencing dual resource dependence because of the legitimacy threat and additional scrutiny that accompanies commercialization. Therefore, it stands to reason that NPOs with dual resource dependency will experience downward pressures on compensation spending.

But according to the nonprofit (Kim, 2017; King and Lewis, 2017) and social entrepreneurship (DTI, 2002; Gras and Mendoza-Abarca, 2014; Haugh, 2005) literature, as social purpose organizations commercialize, they increasingly resemble businesses. Intuitively, entrepreneurial NPOs will come to rely on market-based revenue and, therefore, experience less influence of contributed resource dependence. Instead, entrepreneurial NPOs (at the higher end of the commercialization continuum) experience market-based resource dependence. Marketbased resource dependence constitutes a form of social control of NPOs' choices, commonly experienced by businesses that emanate from paying customers, competitors, and employeesnot primarily motivated by a desire for self-sacrifice and social welfare. Recent studies show that NPOs pursuing commercialization require entrepreneurial expertise and talent (Parris et al., 2018). Therefore, we argue that market-based resource dependence will make the sectoral norms of donative labor motivated compensation strategies untenable for NPOs.

The value of competitive compensation practices for commercial success of organizations (Becker, 1975; Carnahan et al., 2012; Jensen and Murphy, 1990; Lazear and Rosen, 1981) is widely accepted. To acquire and retain top talent, organizations must spend adequately on compensation (Bryant and Allen, 2013). In the for-profit contexts, transactional and selfinterested employment contracts dominate (Thornton et al., 2012). Market-based resource 
dependence subsumes these various forces that collectively stress on the mutually dependent relationship shared between NPOs and their employees. On the high end of the commercialization continuum, we expect there to be a threshold whereby market-based resource dependence comes to eclipse contributed resource dependence. At this point, organizational survival and success is no longer dependent upon securing resources from traditional funding sources, and instead the dependency shifts to attracting and retaining top-tier talent. In sum, we propose a nonlinear (U-shaped) association between commercialization and compensation spending.

Hypothesis 1: There will be a convex relationship between commercialization and compensation spending in NPOs (first negative, then positive).

\subsection{Compensation strategy: Managing Job Roles in Entrepreneurial Nonprofits}

RDT also sheds light on differences in compensation spending by job roles in organizations (Gomez-Mejia and Balkin, 1992; Pfeffer and Davis-Blake, 1987). Specifically, from an RDT perspective, groups and subunits within organizations that harbor competencies and "capabilities that are most needed" garner the most "influence and control over the organization" (Pfeffer and Salancik, 1978: 25). As a result, those roles perceived to provide the most value to the organization come to command the largest share of compensation expenditures within organizations (Pfeffer and Davis-Blake, 1987). We focus on three prominent inter-firm coalitions or job roles in NPOs: administrative, fundraising, and programmatic roles.

Negative views on administrative roles drive conversation around overhead expenses in traditional NPOs and are often regarded as deviation from mission-related spending (Bowman, 2006; Lecy and Searing, 2014). NPOs on the lower end of the commercialization continuum, constrained by contributed resource dependence, will experience pressure to spend less on administrative roles so that they can keep overheads low and efficiency scores high (Callen et al., 
2003). In contrast, as market-based resource dependence comes to dominate NPOs will have the freedom, as well as, the need to spend more on administrative roles. Administrators ensure the seamless co-existence of various of organizational parts, integration of blended goals, and ensure smooth overall operation (Gomez-Mejia and Balkin, 1992; Parris et al., 2018), especially useful to NPOs experiencing dual resource dependence. Therefore, we expect a nonlinear relationship between commercialization and compensation spending on administrative roles in NPOs.

Furthermore, job roles that help organizations "cope with environmental requirements," are considered important strategic employee groups from an RDT perspective (Gomez-Mejia and Balkin, 1992: 25). Both fundraising and programmatic roles meet this criterion. We anticipate fundraising role expenditure to be highest in organizations with high contributed resource dependency because expertise is needed to effectively solicit funds external funders and comply with impact reporting requirements (Thomson, 2010). Studies show fundraising spending efforts pay off in the form of higher charitable contributions to NPOs (Weisbrod and Dominguez, 1986). However, many argue that even with moderate commercial revenue, NPOs will still need contributed revenue since they cannot fully recoup production costs (Kim, 2016), thus requiring expenditures on fundraising roles for entrepreneurial NPOs with a dual resource dependence. As NPOs increase their level of commercialization, they will also need to invest in employees with business expertise who are able to solicit resources from market-based sources. Once marketbased resource dependence effectively eclipses contributed resource dependence we expect to see a drop in fundraising role expenditures because entrepreneurial NPOs will no longer be reliant on contributed sources of revenue and instead will need to invest most heavily in roles requiring business expertise. Therefore, we expect a nonlinear (inverted-U) relationship between commercialization and compensation spending on fundraising roles in NPOs. We expect the 
opposite for NPO programmatic roles.

The nonlinear (U-shaped) associational logic between commercialization and compensation expenditure, applies the most to programmatic job roles in NPOs. Programmatic positions allow NPOs to accomplish their social welfare goals and, thereby, gain sectoral legitimacy (Van Slyke, 2002). While RDT tells us that the greater the value of a job role for a business organization, the more it will spend on compensating those roles (Gomez-Mejia and Balkin, 1992; Pfeffer and Salancik, 1978), employee willingness to accept lower wages for meaningful work remains significant (Franceschini et al., 2015; Nason et al., 2018), especially in mission related roles (Dempsey and Sanders, 2010). Therefore, we expect that the downward pressures of dual resource dependence on compensation spending will be most significant in the programmatic roles, for NPOs trying to balance the need to keep overall compensation expenditures low with the need for both fundraising and business expertise. Logically, as in our first hypothesis, we expect that market-based resource dependence will eclipse contributed resource dependence, after a certain threshold of commercialization and programmatic spending will increase in order for the NPO to more effectively carry out its mission. Thus, we expect a nonlinear (first negative, then positive) association between commercialization and NPO compensation expenditure on programmatic roles.

Hypothesis 2: There will be a nonlinear relationship between commercialization and salary spending by job roles in NPOs, such that:

Hypothesis $2 a$ : For administrative roles, there will be a convex relationship between commercialization and salary spending (first negative, then positive). Hypothesis 2b: For fundraising roles, there will be a concave relationship between commercialization and salary spending (first positive, then negative). Hypothesis 2c: For programmatic roles, there will be a convex relationship between commercialization and salary spending (first negative, then positive).

\subsection{Part-Time Employment in Entrepreneurial Nonprofits}

In for-profit contexts, many highly entrepreneurial organizations tend to use more part-time 
employment (Gomez-Mejia and Balkin, 1992: 92). Due to environmental instability of entrepreneurial settings, more organic organizational arrangements-like part-time employment arrangements - are attractive to for-profit firms. An estimated 27.7 million people in the U.S. work part-time or as temporary or contingent employees, of whom about $77 \%$ voluntary choose to do so and are more than twice as likely to be women (Dunn, 2018).

From an RDT perspective, part-time workers stand to play a different role in NPOs. Most part-time NPO workers do not usually have job security or earn fringe benefits, and some see them as unwaged laborers primarily benefitting the NPOs more than the employees (Baines, 2004). Contingent employees can allow NPOs to optimize their workforce size, reduce slack, and generate value in seasonal sectors like arts and cultural NPOs (De Stefano et al., forthcoming; Paarlberg and Ghosh Moulick, 2017). Entrepreneurship can be disruptive and uncertain for NPOs (Fitzgerald and Shepherd, 2018; Gras and Mendoza-Abarca, 2014; Kirkman, 2012), and part-time labor can help alleviate some of this risk. Part-time employees can provide a broader range of expertise for the same financial investment and can easily be let go if an entrepreneurial foray is unsuccessful, effectively shifting entrepreneurial risk onto employees and away from the organization. We anticipate organizations experiencing dual resource dependence to rely most heavily on part-time contingent labor.

Contingent employment has its downsides as well, which will apply most to NPOs with market-based resource dependence. There is an ongoing discussion about the detrimental effects of part-time workers for organizational success in for-profit contexts. Part-time workers are supposed to be less committed, often associated with operational disruption, breakdown in communication, and slow organizational learning (De Stefano et al., forthcoming). Also, because they spend less time at work, part-time employees tend to "have less work role involvement, less 
positive work attitudes, and higher turnover intentions" (Wittmer and Martin, 2011: 780).

Furthermore, sustaining blended organizational goals are challenging for NPOs. To sustain innovation, organizations must retain talent (Gomez-Mejia and Balkin, 1992). For all these reasons, NPOs on the higher end of the commercialization continuum will experience downward pressure on part-time employment. In essence, once market-based resource dependence eclipses contributed resource dependence, entrepreneurial NPOs will respond by creating full-time positions to retain talent necessary to attract market-based revenue. We expect a nonlinear (inverted-U) association between NPO commercialization and part-time employment.

Hypothesis 3: There will be a concave relationship between commercialization and part-time employment in NPOs (first positive, then negative).

[Table 1 about here]

\section{Methodology, Data, and Variables}

\subsection{Sample}

Compensation practices vary dramatically by sector (Ballou and Weisbrod, 2003). Therefore, to asses similarly situated NPOs, we focus on arts and cultural NPOs in the U.S. Arts and cultural organizations represent a substantial and diverse group of individuals and occupations, encompassing a wide range of artistic, technical, and managerial positions and are archetypal of the overall nonprofit sector. The arts and cultural industry employ nearly 4.8 million individuals with total compensation exceeding $\$ 350$ billion annually in the U.S. (NASAA, 2018). Among artists, $46 \%$ of this workforce is female. But while nearly $78 \%$ of dancers/choreographers are women, two of the highest earning sub-categories of artists - architects and

producers/directors - are overwhelmingly male (75\% and 63\% respectively) (NEA, 2011). Artist occupations tend to have higher educational attainment, with approximately $54 \%$ holding bachelor's degrees or higher, as compared to $26 \%$ of the overall U.S. labor force (NEA, 2008). 
To test our predictions, we acquired our data from DataArts (formerly known as the Cultural Data Project or CDP), a multiyear initiative that compiles an online survey of financial, programmatic, and operational information of arts and cultural 501(c)3 NPOs across all U.S. states. Our sample consists of 4,732 registered 501(c)3 NPOs over the period 2002-2015. After accounting for observations with missing values, we have on average 4.2 years of organizational data. ${ }^{1}$ This dataset provides more nuanced and vetted information than IRS 990 data on arts and cultural NPOs (Charles and Kim, 2016; Kim et al., 2017).

\subsection{Variables}

To test our hypotheses, we assess three facets of NPO compensation strategy using five outcome variables. First, we operationalize compensation spending by calculating the total salary expenditure scaled by total employees, expressed in thousands (Model 1: Sal/Emp). Second, three variables represent compensation by job roles: the ratio of administrative salary exp to total salary expenditure (Model 2: Admin/Sal), the ratio of fundraising salary expenditure to total salary expenditure (Model 3: Fund/Sal), and the ratio of programmatic salary expenditure to total salary expenditure (Model 4: Prog/Sal). Third, contingent employment dependence is operationalized as the ratio of part-time employees to all employees (Model 5: Part/Emp).

Our main predictor is commercialization, operationalized as the level of dependence on market-based revenue in NPOs (\%Commercial), expressed as a proportion. We calculate this as the ratio of market-based revenue to total revenue, following past research in this domain (Gras and Mendoza-Abarca, 2014; Mendoza-Abarca and Gras, 2017). We simultaneously include the

\footnotetext{
${ }^{1}$ The DataArts dataset involves a self-reported survey collected annually from arts \& cultural NPOs (Charles and Kim, 2016; Kim et al., 2017). The methodological philosophy adopted for our analyses was to favor inclusion to enhance generalizability while retaining theoretically relevant control variables. As such, there is a degree of human error in data inputting and many organizations only report information for a year. In addition, careful data cleanup, variable transformations, dynamic modeling, and limiting to those observations available for all variables further reduced our available sample for the final analysis. Important differences exist between NPOs in our sample (mostly larger and mature organizations) and those excluded, as reported in Table A5 in the Appendix.
} 
square term of this variable in our models to test our nonlinear hypotheses.

We also control for the following relevant additional factors: organization age, organizational size, non-market-based revenue, operating efficiency, profitability, competition, board size, and the number of volunteers. Next, we describe each control. Organizational age (Age) is calculated as the difference between the year an NPO was founded from the last year it appears in our sample. Compensation increases with organizational size (Wasserman, 2006). Therefore, we assess organizational size with assets (Schepker et al., 2018) and include the log of assets $(\operatorname{Assets}(\log ))$. To account for revenue from revenue sources other than market-based means (Gras et al. 2014), we account for the proportion of government funding (\%Government) and private donations (\%Donations). We assess operating efficiency in managing resources with return on assets (ROA). It is calculated by dividing NPO's unrestricted total revenue net total expenses by total assets. We also control for profitability (Margin), by calculating the unrestricted total revenue less total expenses divided by unrestricted total revenue. In both cases, unrestricted revenue is free from spending stipulations often set by NPO funders making it the most discretionary funding category in NPOs (Weikart et al., 2012).

Local competition may also exert pressure on compensation and hiring practices. Therefore, we control for competitive pressure by including the number of NPOs that share the same National Information Systems Project (NISP) code in an NPO's county (Competition) in our sample. Boards also play a crucial role of organizational oversight (Fama and Jensen, 1983; Light, 2008; Williamson, 1981) and, when ineffective, can lead to higher compensation (Core et al., 1999). Therefore, we include the number of board members (Board Size). We control for the number of volunteers (Volunteers) to account for access to uncompensated labor. To account for unique compensation trends in different sub-sectors within the arts and culture field, we also 
include binary predictors for NISP codes. Summary statistics and pairwise correlations are presented in Tables 2 and 3, respectively.

\subsection{Model and analysis}

[Tables 2 and 3 about here]

We estimate our five NPO compensation related outcomes using dynamic Generalized Least Square Regression models, with a year lag of the outcomes (StataCorp, 2017; Xu et al., 2019).

Inclusion of squared predictor, based on the nonlinear hypotheses, renders quadratic models. Random unit effects are incorporated to capture NPOs specific differences (Battilana et al., 2015; Xu et al., 2019). Breusch-Pagan and Cook-Weisberg test for heteroskedasticity and the Wooldridge Test for autocorrelation in panel data of the preliminary analyses reveal traces of these problems. Year fixed effects are introduced to allay concern about serial correlation in longitudinal series. All models are adjusted with heteroskedastic robust standard errors clustered by units correcting for within-unit serial correlation (Georgallis et al., 2018; Wooldridge, 2012). Unobservable social-economic, demographic, and labor market factors that vary by state are captured with binary predictors for U.S. states.

\section{Results}

Our findings are presented in Table 4. First, higher levels of commercialization is associated with lower levels of overall compensation spending, programmatic salary spending, and fundraising salary spending. More commercialized NPOs in our sample are also associated with more part-time employees. Second, turning to our main findings, overall salary spending (H1), fundraising salary spending $(\mathrm{H} 2 \mathrm{~b})$, programmatic salary spending $(\mathrm{H} 2 \mathrm{c})$, and part-time employment (H3) all have a statistically significant nonlinear association with the level of commercialization in NPOs. We did not find a statistically significant nonlinear association between administrative salary spending and commercialization (H2). 
[Table 4 about here]

To understand the nonlinear effects better, we plot the predictive margins in Figure 2. First, Figure 2A shows the predicted margins from Model 1. It shows our strongest finding and suggests that the negative association between commercialization on NPOs' overall salary spending, persists beyond the $50 \%$ point of commercialization. In fact, we observed an inflection point only after NPOs generate about $75 \%$ or more commercialization. Second, Figure 2 B was created using predicted margins from Model 3. While we observe an inflection point at about $20 \%$ commercialization, we conclude that the association between commercialization and NPOs' spending on fundraising salary is substantively negative. Third, Figure $2 \mathrm{C}$, was created using predicted margins from Model 4. It shows that when it comes to apportioning salary expenses to programmatic roles, higher commercialization exerts downward pressure on salary spending on programmatic roles until NPOs surpass the $50 \%$ commercialization threshold. Beyond this stage, NPOs with more commercialization spend increasingly more on programmatic roles, as predicted by Hypothesis 2c. Finally, Figure 2D plots predicted margins from Model 5. Again, the expected $50 \%$ threshold of commercialization is seen to be irrelevant. It shows an inverted Ushaped association, as expected, between commercialization and the proportion of part-time employees in sampled NPOs, as predicted by Hypothesis 3. The relationship is first positive but drops off for NPOs that are at about $75 \%$ or more commercialization. Unless NPOs are at a very high stage of commercialization, they do not seem to create full-time positions. Collectively, these findings reveal NPOs at three meaningful stages of commercialization - those at less than $45 \%$ commercialization, those between $45 \%$ to $75 \%$ commercialization, and those at greater than $75 \%$ commercialization.

[Figure 2 about here]

We take several additional steps to ensure the robustness of our findings. First, Ramsey 
RESET test reveal that we improve upon our linear models' specification (without squared term), by adding the second power of our main predictor and by logging right hand side variables. For ease of interpretation, we do not log our predictors. Second, based on the Vuong Likelihood Ratio Test (Vuong, 1989; Wooldridge, 2012) we reject the possibility of equivalence between control models (without main predictors) and reported models in Table 4. Third, we conducted the Hausman specification test on the main effect models to ensure appropriateness of the random unit effects $\left(\chi_{(29)}^{2}=36.30, p=0.17\right)$. Fourth, with autoregressive (AR) random effects GLS models, adjusting for first-order autoregressive disturbances (Baltagi and Wu, 1999; StataCorp, 2017), our overall effect sizes diminish slightly, but our key findings remain unchanged. Fifth, we estimate quantile regressions to assess the effect of covariates at various quantiles of our outcomes (Dimelis and Louri, 2002). Multiple slopes (at $25^{\text {th }}, 50^{\text {th }}, 75^{\text {th }}$, and $90^{\text {th }}$ quantiles) were estimated, spanning the minimum to the maximum values of our outcome variables (Cade and Noon, 2003). The nonlinear effect size of market-based income on salary increases as we move up quantiles of the salary and the program salary variables and decreases with each successive quantile of the part-time employee and fundraising salary variables. Both support our overall conclusions. Sixth, breaking down commercialization into various quantiles (converted to dummy variables) does not offer statistically significant results. It also supports our strategy to test NPO entrepreneurship as a proportion in line with previous empirical studies (Gras and Mendoza-Abarca, 2014; Leroux, 2006). Finally, we do not uncover statistically significant nonlinear effects of commercialization on NPO spending on average fringe benefits.

\section{Discussion}

Market-based resource dependence in NPOs has been a contentious topic with arguments both in favor and against entrepreneurial behavior within NPOs. Our study advances this debate 
by illuminating how increased dependence on commercialization shifts compensation strategy within entrepreneurial NPOs. In our analysis, entrepreneurial NPOs shift risk from entrepreneurial exploration to their employees as they transition from contributed to marketbased resource dependency by relying more heavily on part-time labor. Once commercialization balances and ultimately eclipses contributed revenue, we see entrepreneurial NPOs shifting the composition of their workforce and investing in programmatic salaries and establishing more full-time positions to ensure their long-term success. The NPOs with high commercialization also reflect bold compensation choices, which suggests that market-based revenue provides NPOs the license to be bold and to move beyond externally driven compensation limitations. Together, our findings offer a new perspective on strategic compensation practices in entrepreneurial NPOs.

Our analyses reveal nuanced empirical insights and uncover three contributions to the broader literature by providing a detailed picture of how shifting resource dependencies are managed during commercial transition within entrepreneurial NPOs. First, we find two distinct thresholds in NPO commercialization at which NPOs begin to alter their compensation strategies in response to shifting resource dependency. Past research has emphasized the importance of a $50 \%$ threshold in NPO commercialization, to distinguish between non-commercial and commercial social ventures (DTI, 2002; Gras and Mendoza-Abarca, 2014; Haugh, 2005; Kim, 2017; King and Lewis, 2017). We show that some of the most interesting NPO entrepreneurial choices occur around this halfway point, as NPOs arrive at this transitionary stage and wrestle with dual resource dependencies. In our sample and within the context of various compensation strategies, this occurs between $45 \%$ to $75 \%$ levels of commercialization. We show that once expost market-based resource dependencies come to eclipse ex-ante contributed resource 
dependencies — and the expectations they contain — entrepreneurial NPOs reward talent in highly commercialized NPOs.

Our findings align with our hypotheses, but the threshold surrounding dual resource dependence occurs at a higher level of commercialization than would be explained solely by reliance on revenue. The powerful legacy of nonprofit sectoral expectations appears to last long after their dominance as revenue producers. We interpret this to indicate that contributed resource dependencies extend well beyond direct financial contributions, to cover the panoply of benefits received by NPOs. Unless NPOs are at a very high stage of commercialization (75\% or greater in our sample), they continue to adopt donative labor compensation practices, indicating that NPOs are cautious about boldly defying nonprofit sectoral norms. Only once market-based revenue significantly eclipses contributed revenue are NPOs able to engage in compensation strategies that allow employees to reap the rewards.

This dual threshold offers insight into other research on resource dependency in entrepreneurial NPOs. The fact that dual resource dependence is most pronounced between 45$75 \%$ commercialization in our sample may also explain the finding by Gras and MendozaAbarca (2014) that commercialization greater than 50\% jeopardizes NPO survival, because of added complexity and power imbalance NPOs face at this stage. From a practical standpoint, NPOs considering increasing their level of commercialization need to understand that they will be managing both dependencies until market-based revenues reach a very high level. Surviving the transitory stage of dual resource dependence paves the path to NPO autonomy and bold compensation strategies.

Second, our results show that the tenets of compensation strategy are distinct in entrepreneurial NPOs and offers some preliminary empirical evidence exploring the 
underdeveloped research area of compensation strategies in entrepreneurial contexts (Manne, 2011). While there exists substantial research on compensation strategies in established for-profit and nonprofit organizations, compensation in entrepreneurial NPOs is a distinct area of study and provides a theoretically interesting context for examining the dynamics of shifting resource dependence. Future research may build on these findings by examining alternate antecedents and consequences of either compensation strategies or commercialization in social contexts. Furthermore, our analysis illustrates that workforce composition shifts significantly as contributed resource dependence decreases, allowing commercialized NPOs to focus more on their impact and role within their communities as opposed to seeking contributions.

Third, while balancing contributed and market-based resource dependence in NPOs may be good for their survival (Gras and Mendoza-Abarca, 2014), our study indicates it is not good for the employees of NPOs at the stage of dual resource dependency (45\% to $75 \%$ commercialization in our sample). Entrepreneurial NPOs that find themselves at this stage may exploit employees by having the greatest reliance on part-time labor and the lowest compensation per employee. Therefore, from a compensation perspective, employees of NPOs are worse off under dual resource dependence than they are in those purely dependent on either contributed or market-based resources.

From a practical point of view, hiring part-time workers allows NPOs access to a wider range of skills, which would be necessary for organizations with dual resource dependence, at a lower cost than hiring full-time employees. However, part-time workers are often less committed, often associated with operational disruption, breakdown in communication, slow organizational learning, less positive work attitudes, and higher turnover intentions (De Stefano et al., forthcoming). In addition, most part-time workers do not usually have job security or earn fringe 
benefits, and this practice likely benefits the NPO more than the employees. The expectation that employees should sacrifice compensation that permeates the nonprofit sector becomes even greater in entrepreneurial NPOs with dual resource dependence. Perhaps a strategic dependence on part-time labor is an unintended consequence of funders and overseers exerting pressure on entrepreneurial NPOs to be good stewards of resources. Such pressures, in other contexts, have been associated with NPO managers engaging in various dysfunctional behavior (Krawczyk et al., 2017; Parsons et al., 2017). Our findings illustrate that managers of entrepreneurial NPOs in the transitional stage need to consider how they can effectively manage the downsides of parttime labor force.

We find it notable that while compensation improves at the highest levels of commercialization, it never exceeds the level of compensation when an NPO is wholly dependent on contributed revenue. This indicates that while diversifying revenue sources may be of benefit to the organization, commercialization does not correspond to higher wages for employees once contributed resource dependence has diminished. Studies like Eikenberry and Kluver (2004) warn against commercialization of NPOs as being detrimental to mission value of these organizations. In the case of arts and culture organizations, employees may also be the intended beneficiaries and it is unclear whether the reduction in average salary impacts their organization's ability to achieve their missions. The reliance on the exploitation of donated labor throughout various stages of commercialization raises questions about the responsibilities of NPOs to their stakeholders. Future research should seek to connect shifts in resource dependence with social impact and other organizational outcomes relevant for NPOs.

Limitations of our study offer more opportunities for future research. First, despite the virtues of the highly vetted DataArts sample (e.g. Charles and Kim, 2016; Kim, 2017; Kim and Charles, 
2016; Kim et al., 2017), it allows us to only capture mostly larger mature arts and cultural NPOs in the U.S. Other sectors may have differing compensation practices because they have different skill requirements, particularly in programmatic roles, which may lead to different relationships to the labor market and strategic response. In entrepreneurial contexts, smaller and nascent organizations also tend to act differently. Also, other countries have different regulation relating to NPOs, particularly around their ability to earn revenue from product sales. Therefore, we especially welcome future research to test the generalizability of our findings across sectors and national contexts.

Second, despite the rigor of our empirical analysis, we cannot fully discount the possibility of autocorrelated and heteroskedastic residuals as is the case for many similar studies. To allay concerns of model misspecification, omitted variable bias, heteroskedasticity, and other standard concerns, great care was taken to estimate several different model specifications and additional tests, as discussed in our findings section. Across nearly all models and configurations tested, we consistently observe the same basic pattern of results. Nonetheless, we acknowledge this limitation and encourage caution in interpreting our findings. We welcome future research to test the generalizability of our findings with different data and model specifications.

Third, our data is limited to organizational level total expenditures and does not contain granular breakdowns of compensation by position or demographics. The comparison of executive pay to average worker is an important issue (Kim et al., 2015) and has important implications for pro-social contexts (Mohan et al., 2018). Future research examining differences in compensation across job types in entrepreneurial NPOs would be especially valuable. There may be variation between front line employee and the top echelons of these organizations. The importance of senior managers and leaders (CEO, Board, etc.) is well established in the 
entrepreneurship literature (Daily, 1992). Top managers establish organizational vision and support employees through organizational changes (Breit et al., 2018; Murphy and Coombes, 2009; Steckler and Bartunek, 2012) as they establish a culture of entrepreneurial opportunity seeking, which would justify higher wages to attract and retain talent. Dependence on inexperienced employees can hinder scaling (Battilana and Dorado, 2010), and vertical pay disparity can depress social value creation (Hart et al., 2015). Practically speaking, if entrepreneurial NPOs myopically minimize compensation expenditure in pursuit of social objectives, they risk the long-term viability of their commercial goals and employee welfare.

\section{Conclusion}

Our findings raise significant questions within both the nonprofit management and social entrepreneurship literature streams relating to the central purpose of NPOs and social purpose organizations and their responsibilities to all their stakeholders-employees included. Much of the research and discussion on entrepreneurial NPOs (and social entrepreneurship) has focused on their role within communities, relationship with funders, and efficacy. Less attention has been paid to the impact commercialization has on employees, which represent the third largest sector of workers within the US labor force (Salamon, 2018). Our research offers insights into this important topic and the way employee commitment to mission has been leveraged to shift risk away from entrepreneurial exploration within NPOs. We hope that our findings spark conversation amongst researchers, NPO managers, and policy makers about the responsibilities NPOs have to their employees as they court market opportunities. 
Table 1: Summary of Hypotheses Motivations
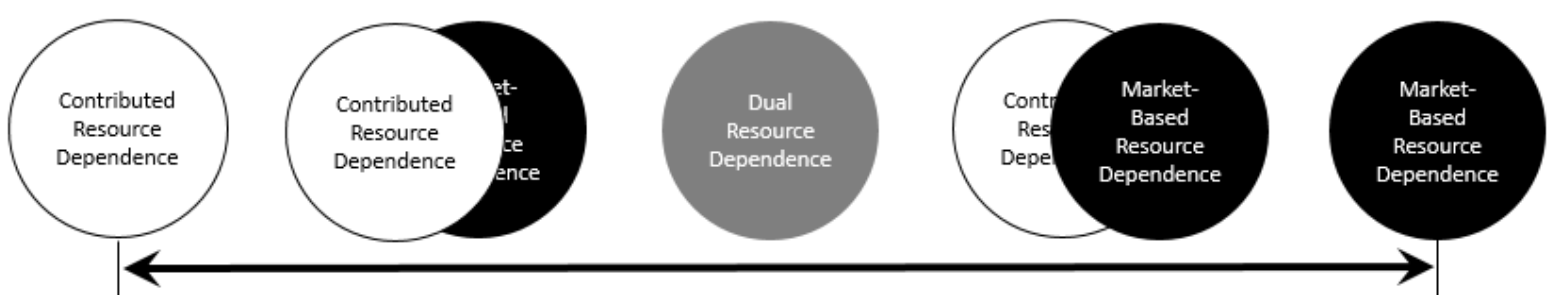

\begin{tabular}{|c|c|c|c|}
\hline$\frac{\sqrt{3}}{\sqrt[3]{3}}$ & $\begin{array}{c}\text { Philanthropic Donors/Funders, } \\
\text { Government Grantors } \\
\text { Tax Payers }\end{array}$ & $\begin{array}{c}\text { Philanthropic Donors/Funders, } \\
\text { Government Grantors, Tax Payers, } \\
\text { Consumers, Employees }\end{array}$ & $\begin{array}{l}\text { Consumers } \\
\text { Employees }\end{array}$ \\
\hline 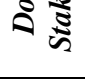 & \multicolumn{3}{|c|}{$\begin{array}{l}\text { Focal organizations (NPOs) must seek to balance legitimacy claims based on level of dependence on resource } \\
\text { providers (Pfeffer \& Salancik, 1978); NPOs with dual resource dependence would face the greatest challenge. }\end{array}$} \\
\hline \multirow[t]{2}{*}{ 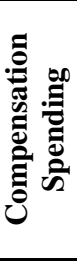 } & $\begin{array}{l}\text { Funder expectation of financial } \\
\text { ratio management exerts } \\
\text { institutional pressure to keep } \\
\text { expenses low. } \\
\text { There is significant reliance on } \\
\text { donative labor }\end{array}$ & $\begin{array}{l}\text { Focal organization is seeking to } \\
\text { appease a wider range of } \\
\text { stakeholders } \\
\text { Legitimacy concerns will cause } \\
\text { NPOs to manage margins more } \\
\text { carefully }\end{array}$ & $\begin{array}{l}\text { Employee contracts are } \\
\text { transactional and self-interested, } \\
\text { requiring focal organizations to } \\
\text { spend more on average to retain top } \\
\text { talent across the organization }\end{array}$ \\
\hline & \multicolumn{3}{|c|}{ H1: There will be a convex relationship between commercialization and compensation spending in NPOs } \\
\hline \multirow{7}{*}{ 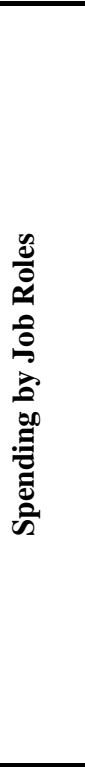 } & \multicolumn{3}{|c|}{$\begin{array}{c}\text { H2: There will be a nonlinear relationship between commercialization and compensation by job roles in } \\
\text { NPOs, such that: }\end{array}$} \\
\hline & $\begin{array}{l}\text { Administrative roles are viewed } \\
\text { negatively because they are } \\
\text { perceived to deviate spending from } \\
\text { mission }\end{array}$ & $\begin{array}{c}\text { Pressure to keep compensation } \\
\text { spending low will intensify to } \\
\text { preserve legitimacy, depressing } \\
\text { administrative spending }\end{array}$ & $\begin{array}{l}\text { Administrative roles are necessary } \\
\text { to integrate blended goals }\end{array}$ \\
\hline & \multicolumn{3}{|c|}{$\begin{array}{c}\text { H2a: For administrative roles, there will be a convex relationship between commercialization and salary } \\
\text { spending }\end{array}$} \\
\hline & $\begin{array}{l}\text { Requires fundraising expertise to } \\
\text { attract resources from contributed } \\
\text { sources }\end{array}$ & $\begin{array}{l}\text { Requires both fundraising and } \\
\text { business expertise }\end{array}$ & $\begin{array}{l}\text { Requires business expertise in } \\
\text { place of fundraising expertise }\end{array}$ \\
\hline & \multicolumn{3}{|c|}{$\begin{array}{c}\text { H2b: For fundraising roles, there will be a concave relationship between commercialization and salary } \\
\text { spending }\end{array}$} \\
\hline & $\begin{array}{l}\text { Programmatic roles help execute } \\
\text { mission in NPOs and are } \\
\text { prioritized }\end{array}$ & $\begin{array}{c}\text { Downward pressure on } \\
\text { compensation spending will be } \\
\text { most acute in programmatic roles } \\
\text { because of employee willingness to } \\
\text { donate labor }\end{array}$ & $\begin{array}{l}\text { Programmatic roles will be } \\
\text { emphasized to preserve legitimacy } \\
\text { and prevent mission drift }\end{array}$ \\
\hline & \multicolumn{3}{|c|}{$\begin{array}{c}\text { H2c: For programmatic roles there will be a convex relationship between commercialization and salary } \\
\text { spending }\end{array}$} \\
\hline \multirow[t]{2}{*}{ 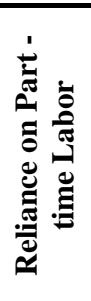 } & $\begin{array}{c}\text { Part-time labor allows for efficient } \\
\text { use of resources but comes with } \\
\text { challenges. }\end{array}$ & $\begin{array}{l}\text { Contingent employees allow NPOs } \\
\text { to optimize workforce size and } \\
\text { reduce risk of pursuing new } \\
\text { market-based strategies }\end{array}$ & $\begin{array}{l}\text { Once market based resource } \\
\text { dependence eclipses contributed } \\
\text { resource dependence, } \\
\text { entrepreneurial NPOs will respond } \\
\text { by creating full time positions to } \\
\text { retain the talent necessary to attract } \\
\text { market-based revenue }\end{array}$ \\
\hline & \multicolumn{3}{|c|}{ H3: There will be a concave relationship between commercialization and part-time employment in NPOs } \\
\hline
\end{tabular}


Table 2: Summary Statistics

\begin{tabular}{|c|c|c|c|c|}
\hline & mean & s.d. & $\min$ & $\max$ \\
\hline Sal/Emp & 26.98961 & 25.15031 & 0.000333 & 2590 \\
\hline Part/Emp & 0.520055 & 0.335349 & 0 & 1 \\
\hline Prog/Sal & 0.495208 & 0.297039 & 0 & 1 \\
\hline Fund/Sal & 0.095112 & 0.094627 & 0 & 1 \\
\hline Admin/Sal & 0.256675 & 0.231043 & 0 & 1 \\
\hline$\%$ Commercial & 0.415682 & 0.257902 & 0 & 1 \\
\hline Age (years) & 43.37737 & 28.21177 & 2 & 161 \\
\hline Assets $(\log )$ & 13.7202 & 2.147138 & 1.386294 & 22.11017 \\
\hline$\%$ Government & 0.126 & 0.183601 & 0 & 1 \\
\hline$\%$ Donations & 0.107374 & 0.125382 & 0 & 0.996039 \\
\hline ROA & 2.221114 & 603.1757 & -28004.7 & 92415 \\
\hline Margin & -0.037 & 0.769441 & -72.4661 & 5.469707 \\
\hline Competition & 36.03535 & 49.45727 & 1 & 210 \\
\hline Volunteers & 136.6119 & 474.7548 & 0 & 21345 \\
\hline Board Size & 17.40198 & 9.707128 & 0 & 58 \\
\hline Dance(1=Yes) & 0.063233 & 0.243385 & 0 & 1 \\
\hline Design Arts(1=Yes) & 0.011019 & 0.104393 & 0 & 1 \\
\hline Folklife/Traditional Arts(1=Yes) & 0.017054 & 0.129476 & 0 & 1 \\
\hline Humanities/Storytelling(1=Yes) & 0.016587 & 0.12772 & 0 & 1 \\
\hline Interdisciplinary(1=Yes) & 0.043687 & 0.204401 & 0 & 1 \\
\hline Literature $(1=$ Yes $)$ & 0.018456 & 0.134595 & 0 & 1 \\
\hline Media Arts(1=Yes) & 0.044816 & 0.206903 & 0 & 1 \\
\hline Multidisciplinary(1=Yes) & 0.283768 & 0.450834 & 0 & 1 \\
\hline Music(1=Yes) & 0.148269 & 0.355374 & 0 & 1 \\
\hline Non-Arts/Non-Humanities(1=Yes) & 0.04065 & 0.197481 & 0 & 1 \\
\hline Opera/Musical Theatre(1=Yes) & 0.037028 & 0.188835 & 0 & 1 \\
\hline Photography(1=Yes) & 0.003972 & 0.062896 & 0 & 1 \\
\hline Theatre(1=Yes) & 0.160534 & 0.367108 & 0 & 1 \\
\hline Visual Arts(1=Yes) & 0.104116 & 0.305416 & 0 & 1 \\
\hline
\end{tabular}


Table 3: Pairwise Correlations

\begin{tabular}{|c|c|c|c|c|c|c|c|c|c|c|c|c|c|c|c|}
\hline & & 1 & 2 & 3 & 4 & 5 & 6 & 7 & 8 & 9 & 10 & 11 & 12 & 13 & 14 \\
\hline 1 & $\mathrm{Sal} / \mathrm{Emp}$ & 1.0000 & & & & & & & & & & & & & \\
\hline 2 & Part/Emp & $-0.6818^{*}$ & 1.0000 & & & & & & & & & & & & \\
\hline 3 & Prog/Sal & $0.2012^{*}$ & $-0.1646 *$ & 1.0000 & & & & & & & & & & & \\
\hline 4 & Fund/Sal & $0.1959^{*}$ & $-0.1354 *$ & $0.0173^{*}$ & 1.0000 & & & & & & & & & & \\
\hline 5 & Admin/Sal & $-0.0467^{*}$ & $-0.0469 *$ & $-0.5265^{*}$ & $-0.2186^{*}$ & 1.0000 & & & & & & & & & \\
\hline 6 & $\%$ Commercial & $-0.1632^{*}$ & $0.1778 *$ & $-0.0651^{*}$ & $-0.1802 *$ & $0.0820^{*}$ & 1.0000 & & & & & & & & \\
\hline 7 & Age & $0.0413 *$ & $0.0159 *$ & $0.0353^{*}$ & 0.0127 & $0.0239^{*}$ & $0.1784 *$ & 1.0000 & & & & & & & \\
\hline 8 & Assets(log) & $0.2128 *$ & $-0.0464 *$ & $0.2115^{*}$ & $0.1527 *$ & $-0.1556 *$ & $0.1124 *$ & $0.3917^{*}$ & 1.0000 & & & & & & \\
\hline 9 & $\%$ Government & $0.0465^{*}$ & $-0.1098 *$ & $0.1303^{*}$ & $-0.1003 *$ & -0.0115 & $-0.3985 *$ & $-0.0451^{*}$ & $-0.0944 *$ & 1.0000 & & & & & \\
\hline 10 & \%Donations & $0.0244 *$ & 0.0063 & $-0.0879 *$ & $0.1066^{*}$ & $0.0307^{*}$ & $-0.2243 *$ & $0.0499^{*}$ & $0.0588^{*}$ & $-0.2164 *$ & 1.0000 & & & & \\
\hline 11 & ROA & $-0.0148^{*}$ & 0.0057 & 0.0050 & 0.0076 & $-0.0142^{*}$ & 0.0004 & 0.0100 & $0.0425 *$ & 0.0050 & -0.0078 & 1.0000 & & & \\
\hline 12 & Margin & $-0.0159 *$ & $0.0152 *$ & -0.0078 & $0.0451^{*}$ & $-0.0144 *$ & $0.0335 *$ & 0.0004 & $0.0344 *$ & $-0.0943^{*}$ & $0.0352 *$ & 0.0025 & 1.0000 & & \\
\hline 13 & Competition & $0.0294 *$ & $0.0202^{*}$ & $-0.0194 *$ & 0.0127 & $-0.1197^{*}$ & $-0.0620^{*}$ & $-0.1201^{*}$ & $-0.0614 *$ & $-0.0471^{*}$ & $-0.0549 *$ & 0.0041 & -0.0020 & 1.0000 & \\
\hline 14 & Volunteers & -0.0032 & $0.0171^{*}$ & $0.0681^{*}$ & $0.0158^{*}$ & $-0.0373^{*}$ & $0.0693^{*}$ & $0.1050^{*}$ & $0.2021^{*}$ & $-0.0430^{*}$ & $0.0139^{*}$ & 0.0012 & $0.0150^{*}$ & $-0.0634 *$ & 1.0000 \\
\hline 15 & Board Size & $0.1367^{*}$ & -0.0047 & $0.0549^{*}$ & $0.1599^{*}$ & $-0.0763^{*}$ & $0.0587 *$ & $0.3523^{*}$ & $0.5701 *$ & $-0.1270^{*}$ & $0.0707 *$ & -0.0029 & $0.0372 *$ & $-0.0603 *$ & $0.1972 *$ \\
\hline 16 & Dance $(1=$ Yes $)$ & $-0.0628^{*}$ & $0.0484 *$ & $-0.1543 *$ & $-0.0794 *$ & $-0.0319^{*}$ & $0.0603 *$ & $-0.0855^{*}$ & $-0.1177 *$ & $-0.0380 *$ & $-0.0523 *$ & 0.0016 & -0.0020 & $0.0237^{*}$ & $-0.0569 *$ \\
\hline 17 & $\begin{array}{l}\text { Design Arts(1=Yes) } \\
\text { Folklife/Traditional }\end{array}$ & $0.0384 *$ & $-0.0363 *$ & 0.0131 & $0.0222 *$ & 0.0133 & -0.0017 & 0.0103 & 0.0096 & 0.0077 & $-0.0262 *$ & 0.0008 & 0.0055 & $-0.0585^{*}$ & 0.0083 \\
\hline 18 & $\begin{array}{l}\text { Arts }(1=\text { Yes }) \\
\text { Humanities/ }\end{array}$ & $-0.0259^{*}$ & -0.0027 & $0.0348^{*}$ & -0.0054 & -0.0075 & 0.0032 & 0.0037 & $-0.0214 *$ & $0.0444^{*}$ & -0.0120 & 0.0010 & -0.0130 & $-0.0793 *$ & $0.0179^{*}$ \\
\hline 19 & Storytelling $(1=$ Yes $)$ & $0.0228^{*}$ & $-0.0302 *$ & $0.0482^{*}$ & 0.0114 & $0.0149^{*}$ & -0.0069 & $0.0536^{*}$ & $0.0752 *$ & $0.0248^{*}$ & $0.0300 *$ & 0.0009 & -0.0132 & $-0.0825 *$ & -0.0041 \\
\hline 20 & Interdisciplinary(1=Yes) & $0.0383^{*}$ & $-0.0391 *$ & $0.0716^{*}$ & 0.0045 & -0.0090 & $-0.0551^{*}$ & $0.0172^{*}$ & $0.0426^{*}$ & $0.0526^{*}$ & $-0.0221 *$ & 0.0016 & -0.0137 & $-0.0972 *$ & -0.0065 \\
\hline 21 & Literature $(1=$ Yes $)$ & $0.0793^{*}$ & $-0.0917 *$ & $0.0540^{*}$ & 0.0129 & -0.0101 & $-0.0437 *$ & $-0.0298 *$ & $-0.0283^{*}$ & $0.0139^{*}$ & 0.0032 & 0.0010 & 0.0036 & $-0.0685^{*}$ & -0.0029 \\
\hline 22 & Media Arts(1=Yes) & $0.0897^{*}$ & $-0.0906^{*}$ & $0.0964 *$ & $0.0198^{*}$ & $-0.0347^{*}$ & $-0.0326^{*}$ & $-0.0635^{*}$ & 0.0073 & 0.0022 & $0.0154 *$ & 0.0015 & 0.0040 & $-0.0910 *$ & 0.0090 \\
\hline 23 & Multidisciplinary $(1=$ Yes $)$ & $0.0790^{*}$ & $-0.0876^{*}$ & $0.2214 *$ & $0.0188^{*}$ & $-0.0270^{*}$ & $-0.0910^{*}$ & -0.0113 & $0.0695^{*}$ & $0.2055^{*}$ & $-0.1003 *$ & -0.0112 & $-0.0201 *$ & $0.1369^{*}$ & $0.0198^{*}$ \\
\hline 24 & $\begin{array}{l}\text { Music }(1=\text { Yes }) \\
\text { Non-Arts/Non- }\end{array}$ & -0.0120 & $0.0887^{*}$ & $-0.2149^{*}$ & $0.0299 *$ & $0.0539^{*}$ & $0.0227^{*}$ & $0.0531^{*}$ & $-0.1105^{*}$ & $-0.1382 *$ & $0.1379 *$ & 0.0030 & $0.0138^{*}$ & $0.0330^{*}$ & $-0.0315^{*}$ \\
\hline 25 & $\begin{array}{l}\text { Humanities(1=Yes) } \\
\text { Opera/Musical }\end{array}$ & $0.0352^{*}$ & $-0.0370^{*}$ & $0.1016^{*}$ & $-0.0147^{*}$ & $-0.0241^{*}$ & $-0.0253^{*}$ & $0.0709^{*}$ & $0.1095^{*}$ & $0.0955^{*}$ & $-0.0227 *$ & 0.0014 & -0.0034 & $-0.1199 *$ & $0.0537 *$ \\
\hline 26 & Theatre(1=Yes) & $-0.0223^{*}$ & $0.0465 *$ & $-0.1055^{*}$ & $0.0209^{*}$ & $0.0511^{*}$ & -0.0012 & 0.0046 & -0.0044 & $-0.0562 *$ & $0.0853 *$ & 0.0013 & -0.0030 & $-0.1183^{*}$ & $-0.0165^{*}$ \\
\hline 27 & Photography(1=Yes) & $0.0144 *$ & $-0.0199 *$ & $0.0202 *$ & 0.0088 & -0.0085 & -0.0085 & -0.0096 & -0.0126 & -0.0044 & -0.0083 & 0.0004 & 0.0004 & $-0.0436 *$ & -0.0133 \\
\hline 28 & Theatre(1=Yes) & $-0.2220^{*}$ & $0.1859^{*}$ & $-0.1889^{*}$ & $-0.0964 *$ & -0.0007 & $0.1220^{*}$ & $-0.1170^{*}$ & $-0.0877^{*}$ & $-0.1103^{*}$ & -0.0069 & 0.0029 & 0.0114 & $0.2297^{*}$ & $0.0226^{*}$ \\
\hline 29 & Visual Arts(1=Yes) & $0.0773 *$ & $-0.0869 *$ & $0.0964 *$ & $0.0777 *$ & $0.0182^{*}$ & -0.0062 & $0.1306^{*}$ & $0.1223 *$ & $-0.0628^{*}$ & 0.0104 & 0.0026 & $0.0192 *$ & $-0.1280 *$ & 0.0013 \\
\hline
\end{tabular}


Table 3: Pairwise Correlations (cont)

\begin{tabular}{|c|c|c|c|c|c|c|c|c|c|c|c|c|c|c|c|c|}
\hline & & 15 & 16 & 17 & 18 & 19 & 20 & 21 & 22 & 23 & 24 & 25 & 26 & 27 & 28 & 29 \\
\hline 1 & Sal/Emp & & & & & & & & & & & & & & & \\
\hline $\begin{array}{l}2 \\
3\end{array}$ & $\begin{array}{l}\text { Part/Emp } \\
\text { Prog/Sal }\end{array}$ & & & & & & & & & & & & & & & \\
\hline 4 & Fund/Sal & & & & & & & & & & & & & & & \\
\hline 5 & Admin/Sal & & & & & & & & & & & & & & & \\
\hline 6 & $\%$ Commercial & & & & & & & & & & & & & & & \\
\hline 7 & Age & & & & & & & & & & & & & & & \\
\hline 8 & Assets $(\log )$ & & & & & & & & & & & & & & & \\
\hline 9 & $\%$ Government & & & & & & & & & & & & & & & \\
\hline 10 & $\%$ Donations & & & & & & & & & & & & & & & \\
\hline 11 & $\mathrm{ROA}$ & & & & & & & & & & & & & & & \\
\hline 12 & Margin & & & & & & & & & & & & & & & \\
\hline 13 & Competition & & & & & & & & & & & & & & & \\
\hline 14 & Volunteers & & & & & & & & & & & & & & & \\
\hline 15 & Board Size & 1.0000 & & & & & & & & & & & & & & \\
\hline 16 & Dance $(1=$ Yes $)$ & $-0.1001 *$ & 1.0000 & & & & & & & & & & & & & \\
\hline 17 & $\begin{array}{l}\text { Design Arts( } 1=\text { Yes }) \\
\text { Folklife/Traditional }\end{array}$ & $0.0310^{*}$ & $-0.0275^{*}$ & 1.0000 & & & & & & & & & & & & \\
\hline 18 & $\begin{array}{l}\text { Arts }(1=\text { Yes }) \\
\text { Humanities/ }\end{array}$ & $-0.0535^{*}$ & $-0.0352 *$ & $-0.0138^{*}$ & 1.0000 & & & & & & & & & & & \\
\hline 19 & Storytelling $(1=$ Yes $)$ & $0.0308 *$ & $-0.0334 *$ & -0.0131 & $-0.0168 *$ & 1.0000 & & & & & & & & & & \\
\hline 20 & Interdisciplinary $(1=Y e s)$ & 0.0071 & $-0.0553 *$ & $-0.0217^{*}$ & $-0.0279 *$ & $-0.0264^{*}$ & 1.0000 & & & & & & & & & \\
\hline 21 & Literature $(1=$ Yes $)$ & $-0.0419^{*}$ & $-0.0364 *$ & $-0.0143 *$ & $-0.0183^{*}$ & $-0.0174 *$ & $-0.0288 *$ & 1.0000 & & & & & & & & \\
\hline 22 & Media Arts(1=Yes) & $-0.0606^{*}$ & $-0.0569 *$ & $-0.0224 *$ & $-0.0287^{*}$ & $-0.0272 *$ & $-0.0450^{*}$ & $-0.0296^{*}$ & 1.0000 & & & & & & & \\
\hline 23 & Multidisciplinary(1=Yes) & -0.0003 & $-0.1654^{*}$ & $-0.0650^{*}$ & $-0.0833^{*}$ & $-0.0790^{*}$ & $-0.1309 *$ & $-0.0861 *$ & $-0.1346^{*}$ & 1.0000 & & & & & & \\
\hline 24 & $\begin{array}{l}\text { Music(1=Yes) } \\
\text { Non-Arts/Non- }\end{array}$ & $0.0394 *$ & $-0.1120 *$ & $-0.0440 *$ & $-0.0564 *$ & $-0.0535^{*}$ & $-0.0887 *$ & $-0.0583 *$ & $-0.0912 *$ & $-0.2649 *$ & 1.0000 & & & & & \\
\hline 25 & $\begin{array}{l}\text { Humanities(1=Yes) } \\
\text { Opera/Musical }\end{array}$ & $0.0469^{*}$ & $-0.0502 *$ & $-0.0197 *$ & $-0.0253^{*}$ & $-0.0240 *$ & $-0.0398 *$ & $-0.0261^{*}$ & $-0.0409 *$ & $-0.1188^{*}$ & $-0.0805^{*}$ & 1.0000 & & & & \\
\hline 26 & Theatre $(1=$ Yes $)$ & $0.0970 *$ & $-0.0514 *$ & $-0.0202 *$ & $-0.0259 *$ & $-0.0245^{*}$ & $-0.0407 *$ & $-0.0267^{*}$ & $-0.0418^{*}$ & $-0.1216^{*}$ & $-0.0823 *$ & $-0.0369 *$ & 1.0000 & & & \\
\hline 27 & Photography(1=Yes) & $-0.0176^{*}$ & $-0.0165^{*}$ & -0.0065 & -0.0083 & -0.0079 & -0.0131 & -0.0086 & -0.0134 & $-0.0390^{*}$ & $-0.0264 *$ & -0.0118 & -0.0121 & 1.0000 & & \\
\hline 28 & Theatre $(1=$ Yes $)$ & $-0.0259 *$ & $-0.1182 *$ & $-0.0464 *$ & $-0.0595 *$ & $-0.0564^{*}$ & $-0.0936 *$ & $-0.0615^{*}$ & $-0.0962 *$ & $-0.2796^{*}$ & $-0.1893 *$ & $-0.0849 *$ & $-0.0869 *$ & $-0.0279 *$ & 1.0000 & \\
\hline 29 & Visual Arts(1=Yes) & $0.0400 *$ & $-0.0902 *$ & $-0.0355^{*}$ & $-0.0455^{*}$ & $-0.0431^{*}$ & $-0.0714 *$ & $-0.0470 *$ & $-0.0734 *$ & $-0.2135^{*}$ & $-0.1446^{*}$ & $-0.0648^{*}$ & $-0.0663^{*}$ & $-0.0213^{*}$ & $-0.1525^{*}$ & 1.0000 \\
\hline
\end{tabular}


Table 4: Commercial Revenue and NPO Compensation Strategy

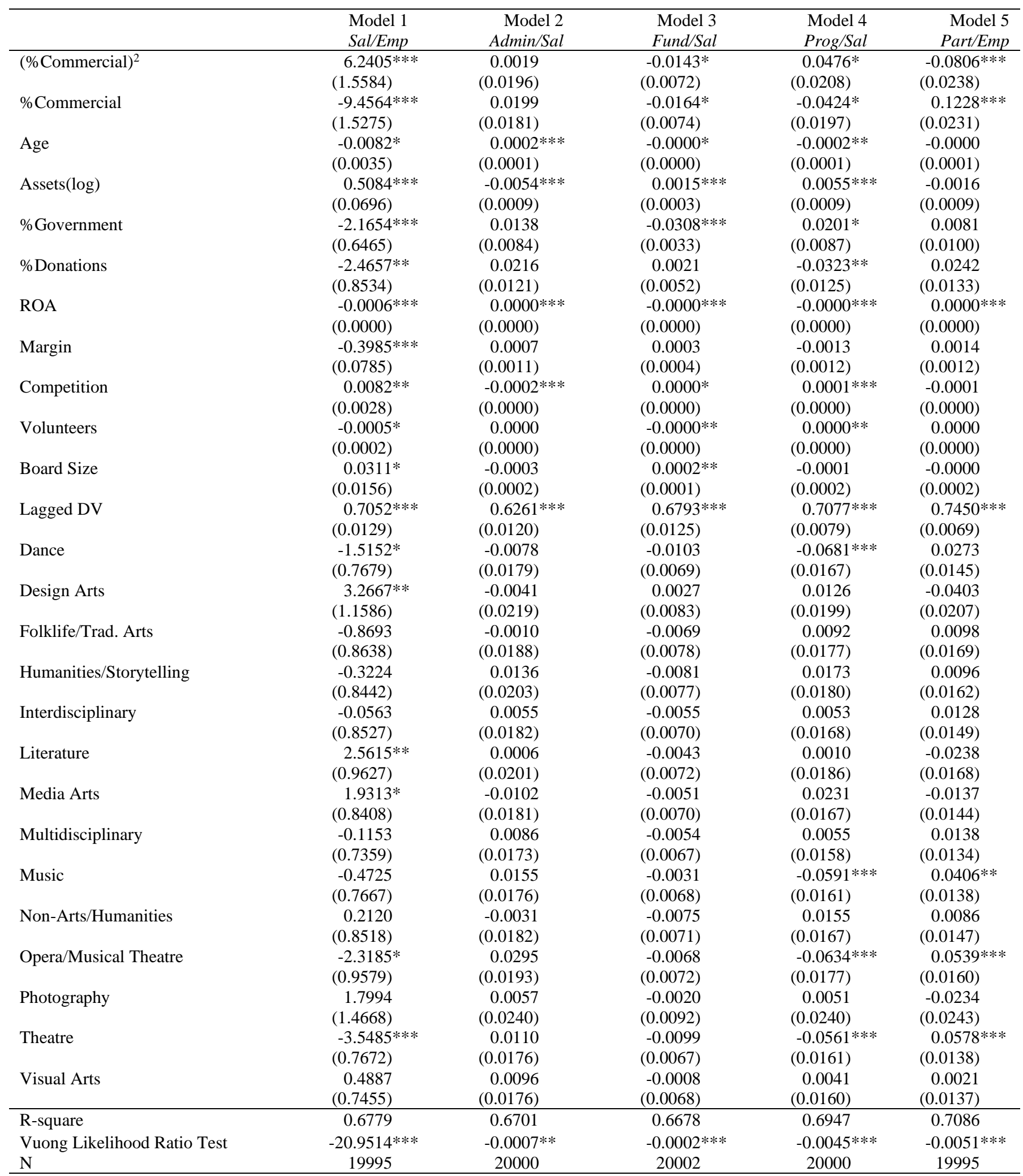

Cluster(id) s.e.; Two-tailed tests of significance; Unit r.e.; US state and year f.e

$* \mathrm{p}<0.05, * * \mathrm{p}<0.01, * * * \mathrm{p}<0.001$ 
Figure 1: NPO Commercialization Continuum
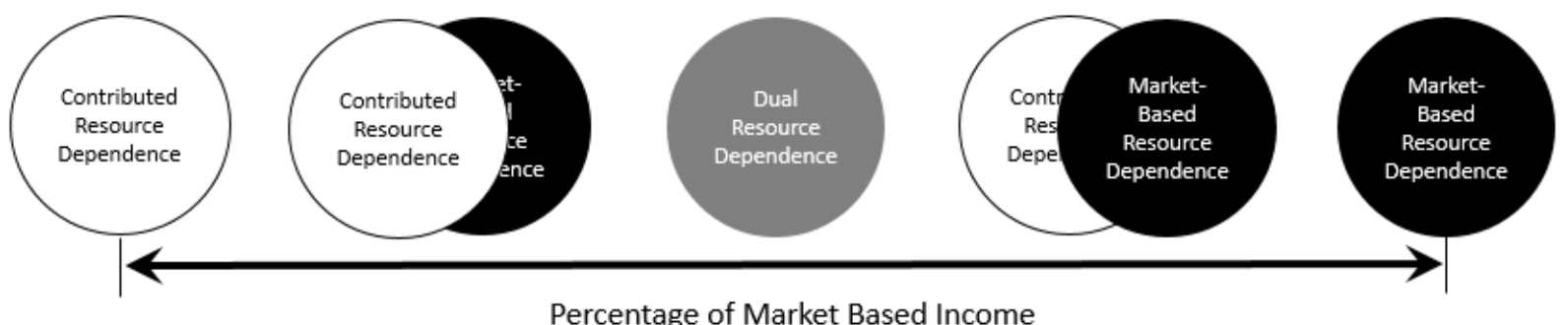

Percentage of Market Based Income

$0 \%$

Low Commercialization

High Commercialization

Figure 2: Predictive Margins with Dependent Variables

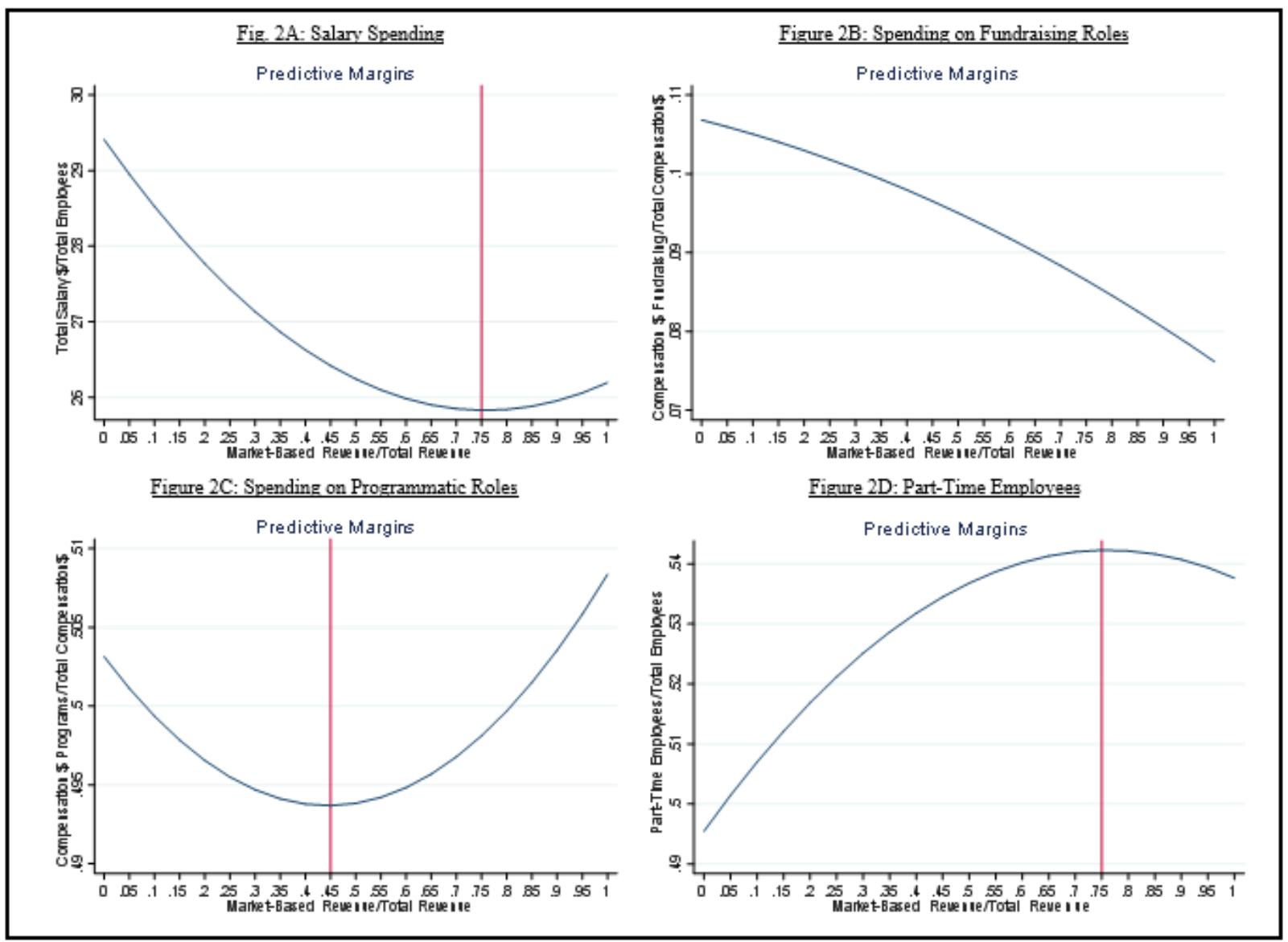




\section{REFERENCES}

Abdelgawad S.G., Zahra S.A., Svejenova S., Sapienza H.J. Strategic leadership and entrepreneurial capability for game change. Journal of leadership \& organizational studies 2013;20:394-407.

Baines D. Caring for nothing: Work organization and unwaged labour in social services. Work, Employment, and Society 2004;18:267-295.

Ballou J., Weisbrod B.A. Managerial rewards and the behavior of for-profit, governmental, and nonprofit organizations: Evidence from the hospital industry. Journal of Public Economics 2003;87:1895-1920. Baltagi B.H., Wu P.X. Unequally spaced panel data regressions with $A R(1)$ disturbances. Econometric Theory 1999;15:814-823.

Battilana J., Dorado S. Building sustainable hybrid organizations: The case of commercial microfinance organizations. Academy of Management Journal 2010;53:1419-1440.

Battilana J., Lee M. Advancing research on hybrid-organizing: Insights from the study of social

enterprises. The academy of Management Annals 2014;8:397-441.

Battilana J., Sengul M., Pache A.-C., Model J. Harnessing productive tensions in hybrid organizations: The case of work integration social enterprises. Academy of Management Journal 2015;58:1658-1665.

Becker G.S. Human Capital: A Theoretical and Empirical Analysis, with Special Reference to Education. 2 ed. New York: Columbia University Press; 1975.

Benzing C., Leach E., McGee C. Sarbanes-Oxley and the new form 990: Are arts and culture nonprofits ready? Nonprofit \& Voluntary Sector Quarterly 2011;40:1132-1147.

Bowman W. Should Donors Care About Overhead Costs? Do They Care? Nonprofit and Voluntary Sector Quarterly 2006;35:288-310.

Breit E., Fossestol K., Andreassen T. From pure to hybrid professionalism in post-NPM activation reform: The institutional work of frontline managers. Journal of Professions and Organization 2018;5:28-44. Brown M. The Moralization of Commercialization: Uncovering the History of Fee-Charging in the US Nonprofit Human Services Sector. Nonprofit and Voluntary Sector Quarterly 2018.

Bryant P.C., Allen D.G. Compensation, benefits and employee turnover: HR strategies for retaining top talent. Compensation \& Benefits Review 2013;45:171-175.

Bureau of Labor Statistics U.S.D.o.L. Nonprofits account for 12.3 million jobs, 10.2 percent of private sector employment, in 2016. The Economics Daily. BLS; 2018.

Cade B.S., Noon B.R. A gentle introduction to quantile regression for ecologists. Frontiers in Ecology and the Environment 2003;1:412-420.

Callen J.L., Klein A., Tinkelman D. Board Composition, Committees, and Organizational Efficiency: The Case of Nonprofits. Nonprofit \& Voluntary Sector Quarterly 2003;32:493-520.

Carnahan S., Agarwal R., Campbell B.A. Heterogeneity in turnover: The effect of relative compensation dispersion of firms on the mobility and entrepreneurship of extreme performers. Strategic Management Journal 2012;33:1411-1430.

Carroll D.A., Stater K.J. Revenue diversification in nonprofit organizations: Does it lead to financial stability? . Journal of public administration research and theory 2008;19:947-966.

Casciaro T., Pirskorki M.J. Power imbalance, mutual dependence, and constraint absorbtion: A closer look at resource dependence theory. Administrative Science Quarterly 2005;50:167-199.

Charles C., Kim M. Do Donors Care About Results? An Analysis of Nonprofit Arts and Cultural

Organizations. Public Performance \& Management Review 2016;39:864-884.

Chikoto G.L., Neely D.G. Building nonprofit financial capacity: the impact of revenue concentration and overhead costs. Nonprofit \& Voluntary Sector Quarterly 2014;43:570-588.

Corbett A. The myth of the intrapreneur. Harvard Busines Review. 2018.

Core J.E., Holthausen R.W., Larcker D.F. Corporate governance, chief executive officer compensation, and firm performance. Journal of Financial Economics 1999;51.

Cyert R.M., March J.G. A behavioral theory of the firm. 2 ed. Englewood Cliffs, NJ: Wiley-Blackwell; 1963. Daily C.M., Dalton, D. R. . The relationship between governance structure and corporate performance in entrepreneurial firms. Journal of Business Venturing 1992;7:375-386. 
De Stefano F., Bonet R., Camuffo A. Does losing temporary workers matter? The effects of planned turnover on replacements and unit performance. Academy of Management Journal forthcoming. Dees J.G. Enterprising nonprofits. Harvard Business Review 1998:55-67.

Dees J.G. Taking social entrepreneurship seriously. Society 2007;44:24-31.

Dees J.G. A tale of two cultures: Charity, problem solving, and the future of social entrepreneurship. Journal of Business Ethics 2012;111:321-334.

Dempsey S.E., Sanders M.L. Meaningful work? Nonprofit marketization and work/life imbalance in popular autobiographies of social entrepreneurship. Organization 2010;17:437-459.

Dimelis S., Louri H. Foreign ownership and production efficiency: a quantile regression analysis. Oxford Economic Papers 2002;54:449-469.

DTI. Social enterprise: A strategy for success. UK: Department of Trade and Industry; 2002.

Dunn M. Who chooses part-time work and why? Monthly Labor Review. US Bureau of Labor Statistics; 2018. p. 1-25.

Eikenberry A.M., Kluver J.D. The marketization of the nonprofit sector: Civil society at risk? Public Administration Review 2004;64:132-140.

Fama E.F., Jensen M.L. Separation of ownership from control. Journal of Law and Economics 1983;26:301-325.

Fitzgerald T., Shepherd D. Emerging Structures for Social Enterprises Within Nonprofits: An Institutional Logics Perspective. Nonprofit \& Voluntary Sector Quarterly 2018;47:474-492.

Franceschini L., Wang J., Cart T. Rising leaders on environmental sustainability and climate change: A global survey of business students. New Haven, CT: Yale Center for Business and the Environment; 2015. Froelich K.A. Diversification of revenue strategies: Evolving resource dependence in non-profit organizations. Non-Profit and Voluntary Sector Quarterly 1999;28:246-268.

Georgallis P.P., Dowell G., Durand R. Shine on me: Industry coherence and policy support for emerging industries. Adminstrative Science Quarterly 2018.

Gomez-Mejia L.R., Balkin D.B. Compensation, organizational strategy and firm performance. SouthWestern Publishing Company; 1992.

Gras D., Mendoza-Abarca K.I. Risky business? The survival implications of exploiting commercial opportunities by nonprofits. Journal of Business Venturing 2014;29:392-404.

Gregory A.G., Howard D. The nonprofit starvation cycle. Stanford Social Innovation Review 2009;7:49-

53.

Gronbjerg K.A. How nonprofit human service organizations manage their funding sources: Key findings and policy implications. Nonprofit Management \& Leadership 1991;2:159-175.

Hansmann H.B. Reforming nonprofit corporation law. University of Pennsylvania Law Review 1981;129:497.

Hart T.A., David P., Shao F., Fox C.J., Westermann-Behaylo M. An examination of the impact of executive compensation disparity on corporate social performance. Strategic Organization 2015;13:200-223. Haugh H. A research agenda for social entrepreneurship. Social Enterprise Journal 2005;1:1-12. Hitt M.A., Ireland R.D., Sirmon D.G., Trahms C.A. Strategic entrepreneurship: Creating value for individuals, organizations, and society. Academy of Management Perspectives 2011;25:57-75. Hoskisson R.E., Gambeta E., Green C.D., Li T.X. Is my firm-specific investment protected? Overcoming the stakeholder investment dilemma in the resource-based view. Academy of Management Review 2018;43:284-306.

Ireland R.D., Hitt M.A., Sirmon D.G. A Model of Strategic Entrepreneurship: The Construct and its Dimensions. Journal of Management 2003;29:963-989.

Jensen M.C., Murphy K.T. Performance pay and top-management incentives. Journal of Political Economy 1990;98:225-264.

Keating E.K., Fischer M., Gordon T.P., Greenlee J.S. Assessing financial vulnerability in the nonprofit sector. In: Hauser Center for Nonprofit Organizations J.F.K.S.o.G., Harvard University editor editors. Faculty Research Working Paper Series. 2005. 
Kim J., Kogurt B., Yang J. Executive compensation, fat cats, and best athletes. American Sociological Review 2015;80:299-328.

Kim M. The Relationship of Nonprofits' Financial Health to Program Outcomes: Empirical Evidence From Nonprofit Arts Organizations. Nonprofit and Voluntary Sector Quarterly 2016;46:525-548.

Kim M. Characteristics of Civically Engaged Nonprofit Arts Organizations. Nonprofit and Voluntary Sector Quarterly 2017;46:175-198.

Kim M., Charles C. Assessing the strength and weakness of the DataArts Cultural Data Profile in comparison with the NCCS 990 Data. Journal of Public Budgeting, Accounting \& Financial Management 2016;28:337-360.

Kim M., Pandey S., Pandey S.K. Why do nonprofit performing arts organizations offer free public access? Public Administration Review 2017.

King C., Lewis G.B. Nonprofit Pay in a Competitive Market: Wage Penalty or Premium? Nonprofit and Voluntary Sector Quarterly 2017;46:1073-1091.

Kirkman D. Social enterprises: An multi-level framework of the innovation adoption process. Innovation: Management, Policy \& Practice 2012;14:143-155.

Klein P.G., Mahoney J.T., McGahan A.M., Pitelis C.N. Capabilities and Strategic Entrepreneurship in Public Organizations. Strategic Entrepreneurship Journal 2013;7:70-91.

Knutsen W.L., Chan Y. The Phenomenon of Staff Volunteering: How Far Can You Stretch the Psychological Contract in a Nonprofit Organization? Voluntas: International Journal of Voluntary and Nonprofit Organizations 2014;26:962-983.

Krawczyk K., Wooddell M., Dias A. Charitable Giving in Arts and Culture Nonprofits: The Impact of Organizational Characteristics. Nonprofit and Voluntary Sector Quarterly 2017;46:817-836.

Lazear E.P., Rosen S. Rank order tournaments as an optimum labor contract. Journal of Political Economy 1981;89:841-864.

Lecy J.D., Searing E.A.M. Anatomy of the Nonprofit Starvation Cycle: An Analysis of Falling Overhead Ratios in the Nonprofit Sector. Nonprofit and Voluntary Sector Quarterly 2014;44:539-563.

Leroux K.M. What drives nonprofit entrepreneurship? A look at budget trends of Metro-Detroit social service agencies. The American Review of Public Administration 2006;35:350-362.

Light P.C. The search for social entrepreneurship. Brookings Institution Press; 2008.

Lyons T.S., Kickul J.R. The social enterprise financing landscape: The lay of the land and new research on the horizon. Entrepreneurship Research Journal 2013;3:147-159.

Manne H.G. Entrepreneurship, compensation, and the corporation. The Quarterly Journal of Austrian Economics 2011;14:3-24.

Margolis J.D., Walsh J.P. Misery loves companies: Rethinking social initiatives by business. Administrative Science Quarterly 2003;48:268-305.

Mendoza-Abarca K.I., Gras D. The Performance Effects of Pursuing a Diversification Strategy by Newly Founded Nonprofit Organizations. Journal of Management 2017:014920631668585.

Milkovich G.T., Newman J.M. Compensation. New York: McGraw-Hill/Irwin; 2008.

Mitchell R.K., Agle B.R., Wood D.J. Toward a theory of stakeholder identification and salience: Defining the principle of who and what really counts. Academy of Management Review 1997;22:853-886.

Mohan B., Schlager T., Deshpandé R., Norton M.I. Consumers Avoid Buying From Firms With Higher CEOto-Worker Pay Ratios. Journal of Consumer Psychology 2018;28:344-352.

Moss T., Short J., Payne G.T., Lumpkin G.T. Dual identities in social ventures: an exploratory study. Entreprenuership Theory and Practice 2011;35.

Murphy P.J., Coombes S.M. A model of social entrepreneurial discovery. Journal of Business Ethics 2009;87:325-336.

NASAA. Creative Work Force State Profiles National Assembly of State Arts Agencies; 2018.

Nason R.S., Bacq S.C., Gras D. A behavioral theory of social performance: social identity and stakeholder expectations. Academy of Management Review 2018;43:259.

NEA. Artists in the Workforce: 1990-2005. NEA Research Report. National Endowment of the Arts; 2008. 
NEA. Artists and Arts Workers in the United States: Findings from the American Community Survey (2005-2009) and the Quarterly Census of Employment and Wages (2010). NEA Research Note. National Endowment for the Arts; 2011.

Nielson R.P. Piggybacking strategies for nonprofits: A shared costs approach. Strategic Management Journal 1986;7:201-215.

Oster S. Strategic Management for Nonprofit Organizations: Theory and Cases. New York: Oxford University Press; 1995.

Paarlberg L.E., Ghosh Moulick A. Captured by Partners: Interorganizational Relationships and Fund

Allocation Stability in United Way Systems. International Public Management Journal 2017;20:356-380.

Pache A.-C., Santos F.M. Inside the hybrid organization: Selective coupling as a response to competing institutional logics. Academy of Management Journal 2013;56:972-1001.

Parris D.L., Alexiou K., Dowin Kennedy E., Linnane M.S. Start with What You Have: A leader's path to innovation. Organizational Dynamics 2018.

Parsons L.M., Pryor C., Roberts A.A. Pressure to manage ratios and willingness to do so: Evidence from nonprofit managers. Nonprofit \& Voluntary Sector Quarterly 2017;46:705-724.

Pfeffer J. Organizations and Organization Theory. Boston, MA: Pittman; 1982.

Pfeffer J., Davis-Blake A. Understanding organizational wage structures: A resource dependence approach. Academy of Management Journal 1987;30:437-455.

Pfeffer J., Salancik G.R. The External Control of Organizations: A Resource Dependence Perspective. New York, NY: Harper \& Row; 1978.

Preston A.E. The nonprofit worker in a for-profit world. Journal of Labor Economics, 1989;7:438-463.

Risi D., Wickert C. Reconsidering the 'symmetry' between institutionalization and professionalization:

The case of corporate social responsibility managers. Journal of Management Studies 2016;54:613-646.

Rose-Ackerman S. Altruism, nonprofits, and economic theory. Journal of economic Literature 1996;34:701-728.

Salamon L.M. America's Nonprofit Sector: A Primer. New York: The Foundation Center; 1999.

Salamon L.M. Scope and structure: The anatomy of America's nonprofit sector. In: Ott J.S. editor editors. The Nature of the Nonprofit Sector. Boulder, CO: Westview Press; 2001a. p. 23-39.

Salamon L.M. What is the nonprofit sector and why do we have it? In: Ott J.S. editor editors. The nature of the nonprofit sector. Boulder, CO: Westview Press; 2001b. p. 162-166.

Salamon L.M. Nonprofits: America's third largest workforce. Nonprofit Economic Data Project.

Baltimore, MD: Johns Hopkins for Civil Society Studies; 2018.

Schepker D.J., Nyberg A.J., Ulrich M.D., Wright P.M. Planning for future leadership: Procedural rationality, formalized succession processes, and CEO influence in CEO succession planning. Academy of Management Journal 2018;61:523-552.

Smith B.R., Cronley M.L., Barr T.F. Funding implications of social enterprise: The role of mission consistency, entreprenuerial competence, and attitude toward social enterprise on donor behavior. Journal of Public Policy \& Marketing 2012;31:142-157.

StataCorp. Stata: Release 15. Statistical Software. . College Station, TX: StataCorp LLC; 2017.

Steckler E., Bartunek J. Revealing themes: Applying a positive lens to the chapters on change agency. . In: K. Golden-Biddle e.a. editor editors. Using a positive lens to explore social change and organizations: Building a theoretical and research foundation New York: Routledge/Taylor and Francis Group. ; 2012. Taylor L.L. Updating the Wyoming Hedonic Wage Index. A report prepared for the Wyoming Joint Appropriations and Joint Education Committees 2011.

Thomson D.E. Exploring the role of funders' performance reporting mandates in nonprofit performance management. Nonprofit and Voluntary Sector Quarterly 2010;39:611-629.

Thornton P.H., Ocasio W., Lounsbury M. The institutional logics perspective: A new approach to culture, structure, and process. Oxford, UK: Oxford University Press; 2012.

Vuong Q.H. Likelihood ratio tests for model selection and non-nested hypotheses. . Econometrica:

Journal of the Econometric Society 1989;57:307-333. 
Wasserman N. Stewards, agents, and the founder discount: Executive compensation in new ventures. Academy of Management Journal 2006;49:960-976.

Weikart L.A., Chen G.G., Sermier E. Budgeting and financial management for nonprofit organizations. Washington, DC: CQ Press; 2012.

Weisbrod B.A., Dominguez N.D. Demand for collective goods in private nonprofit markets: Can fundraiser expenditures help overcome free-rider behavior. Journal of Public Economics 1986;30:83-95. Wickert C., de Bakker F.G.A. Pitching for social change: Towards a relational approach to selling and buying social issues. Academy of Management Discoveries 2018;4:50-73.

Williamson $\mathrm{O}$. The economics of organization: The transaction cost approach. American Journal of Sociology 1981;87:548-577.

Wittmer J.L.S., Martin J.E. Work and personal role involvement of part-time employees: Implications for attitudes and turnover intentions. Journal of Organizational Behavior 2011;32:767-787.

Wooldridge J.M. Introductory Econometrics: A modern approach. Boston: Cengage Learning; 2012. Xu R., DeShon R.P., Dishop C.R. Challenges and opportunities in the estimation of dynamic models. Organizational Research Methods 2019. 


\section{Appendix A}

Table A5: Sample Differences Between Organizations Included and Excluded in Analyses

\begin{tabular}{|c|c|c|c|c|c|c|c|c|c|c|c|c|c|c|c|c|c|c|}
\hline \multirow[b]{3}{*}{ Sal/Emp (\$1000) } & \multicolumn{5}{|c|}{ Not in sample } & \multicolumn{5}{|c|}{ In sample } & \multicolumn{5}{|c|}{ Combined } & \multirow{3}{*}{$\frac{t}{-29.4735}$} & \multirow{3}{*}{$\frac{\text { d.f. }}{42406}$} & \multirow{3}{*}{$\frac{p \text {-value** }}{0.0000}$} \\
\hline & $\mathrm{N}$ & mean & s.d. & $95 \%$ Co & Interval & $\mathrm{N}$ & mean & s.d. & $95 \%$ Con & Interval & $\mathrm{N}$ & mean & s.d. & $95 \% \mathrm{Co}$ & Interval & & & \\
\hline & 16725 & 20.2866 & 18.8952 & 20.0003 & 20.5730 & 25683 & 26.9896 & 25.1503 & 26.6820 & 27.2972 & 42408 & 24.3461 & 23.1215 & 24.1260 & 24.5661 & & & \\
\hline Part/Emp & 16725 & 0.5911 & 0.3867 & 0.5853 & 0.5970 & 25683 & 0.5201 & 0.3353 & 0.5160 & 0.5242 & 42408 & 0.5481 & 0.3582 & 0.5447 & 0.5515 & 20.0671 & 42406 & 0.0000 \\
\hline Prog/Sal & 16715 & 0.3696 & 0.3562 & 0.3642 & 0.3750 & 25691 & 0.4951 & 0.2971 & 0.4915 & 0.4987 & 42406 & 0.4456 & 0.3275 & 0.4425 & 0.4488 & -39.2697 & 42404 & 0.0000 \\
\hline Fund/Sal & 16716 & 0.0550 & 0.0947 & 0.0536 & 0.0565 & 25691 & 0.0951 & 0.0946 & 0.0939 & 0.0963 & 42407 & 0.0793 & 0.0967 & 0.0784 & 0.0802 & -42.5766 & 42405 & 0.0000 \\
\hline Admin/Sal & 16715 & 0.4198 & 0.3633 & 0.4143 & 0.4253 & 25691 & 0.2567 & 0.2310 & 0.2539 & 0.2595 & 42406 & 0.3210 & 0.3012 & 0.3181 & 0.3238 & 56.4936 & 42404 & 0.0000 \\
\hline$\%$ Commercial & 37660 & 0.3991 & 0.2872 & 0.3962 & 0.4020 & 25691 & 0.4157 & 0.2579 & 0.4125 & 0.4188 & 63351 & 0.4058 & 0.2758 & 0.4037 & 0.4080 & -7.4421 & 63349 & 0.0000 \\
\hline Age (years) & 37153 & 30.8782 & 26.0344 & 30.6134 & 31.1429 & 25691 & 43.3748 & 28.2092 & 43.0299 & 43.7198 & 62844 & 35.9869 & 27.6360 & 35.7708 & 36.2029 & -57.1580 & 62842 & 0.0000 \\
\hline Assets $(\log )$ & 28146 & 1.3157 & 4.1071 & 1.2677 & 1.3637 & 25691 & 13.7195 & 2.1474 & 13.6932 & 13.7457 & 53837 & 7.0287 & 7.0287 & 7.1754 & 7.2941 & -430.0000 & 53835 & 0.0000 \\
\hline$\%$ Government & 37650 & 0.1089 & 0.1681 & 0.1072 & 0.1106 & 25691 & 0.1260 & 0.1836 & 0.1237 & 0.1282 & 63341 & 0.1158 & 0.1747 & 0.1145 & 0.1172 & -12.1112 & 63339 & 0.0000 \\
\hline$\%$ Donations & 37645 & 0.1140 & 0.1526 & 0.1124 & 0.1155 & 25691 & 0.1074 & 0.1254 & 0.1058 & 0.1089 & 63336 & 0.1113 & 0.1422 & 0.1102 & 0.1124 & 5.7532 & 63334 & 0.0000 \\
\hline ROA & 2806 & -0.1832 & 13.0247 & -0.6653 & 0.2990 & 25691 & 2.2205 & 603.0818 & -5.1544 & 9.5954 & 28497 & 1.9838 & 572.6348 & -4.6650 & 8.6327 & -0.2111 & 28495 & 0.8328 \\
\hline Margin & 37594 & -0.5852 & 78.3783 & -1.3775 & 0.2071 & 25691 & -0.0370 & 0.7693 & -0.0464 & -0.0276 & 63285 & -0.3627 & 60.4117 & -0.8333 & 0.1080 & -1.1211 & 63283 & 0.2622 \\
\hline Competition & 37758 & 35.7235 & 46.3610 & 35.2558 & 36.1911 & 25691 & 36.0264 & 49.4524 & 35.4216 & 36.6311 & 63449 & 35.8461 & 47.6368 & 35.4754 & 36.2168 & -0.7862 & 63447 & 0.4317 \\
\hline Volunteers & 37758 & 60.9408 & 294.0834 & 57.9744 & 63.9072 & 25691 & 136.5795 & 474.6848 & 130.7747 & 142.3842 & 63449 & 91.5675 & 379.5769 & 88.6139 & 94.5210 & -24.7578 & 63447 & 0.0000 \\
\hline Board Size & 37141 & 0.0912 & 0.2880 & 9.5054 & 9.6491 & 25691 & 17.4005 & 9.7066 & 17.2818 & 17.5192 & 62832 & 12.77604 & 9.1022 & 12.7049 & 12.8472 & 12.7806 & 63445 & 0.0000 \\
\hline Dance $(1=Y e s)$ & 37756 & 0.0912 & 0.2880 & 0.0883 & 0.0941 & 25691 & 0.0633 & 0.2434 & 0.0603 & 0.0662 & 63447 & 0.0799 & 0.2712 & 0.0778 & 0.0820 & 12.7806 & 63445 & 0.0000 \\
\hline Design $\operatorname{Arts}(1=Y e s)$ & 37756 & 0.0047 & 0.0685 & 0.0040 & 0.0054 & 25691 & 0.0110 & 0.1044 & 0.0097 & 0.0123 & 63447 & 0.0073 & 0.0849 & 0.0066 & 0.0079 & -9.1793 & 63445 & 0.0000 \\
\hline Folklife/Traditional Arts(1=Yes) & 37756 & 0.0298 & 0.1700 & 0.0281 & 0.0315 & 25691 & 0.0170 & 0.1295 & 0.0155 & 0.0186 & 63447 & 0.0246 & 0.1550 & 0.0234 & 0.0258 & 10.1766 & 63445 & 0.0000 \\
\hline Humanities/Storytelling(1=Yes) & 37756 & 0.0079 & 0.0883 & 0.0070 & 0.0088 & 25691 & 0.0166 & 0.1277 & 0.0150 & 0.0181 & 63447 & 0.0114 & 0.1061 & 0.0106 & 0.0122 & -10.1610 & 63445 & 0.0000 \\
\hline Interdisciplinary $(1=$ Yes $)$ & 37756 & 0.0423 & 0.2013 & 0.0403 & 0.0443 & 25691 & 0.0437 & 0.2044 & 0.0412 & 0.0462 & 63447 & 0.0429 & 0.2025 & 0.0413 & 0.0444 & -0.8394 & 63445 & 0.4012 \\
\hline Literature $(1=\mathrm{Yes})$ & 37756 & 0.0285 & 0.1663 & 0.0268 & 0.0302 & 25691 & 0.0185 & 0.1347 & 0.0168 & 0.0201 & 63447 & 0.0244 & 0.1544 & 0.0232 & 0.0256 & 7.9997 & 63445 & 0.0000 \\
\hline Media Arts(1=Yes) & 37756 & 0.0331 & 0.1790 & 0.0313 & 0.0349 & 25691 & 0.0448 & 0.2070 & 0.0423 & 0.0474 & 63447 & 0.0379 & 0.1909 & 0.0364 & 0.0394 & -7.5861 & 63445 & 0.0000 \\
\hline Multidisciplinary $(1=\mathrm{Yes})$ & 37756 & 0.2387 & 0.4263 & 0.2344 & 0.2430 & 25691 & 0.2837 & 0.4508 & 0.2782 & 0.2892 & 63447 & 0.2569 & 0.4369 & 0.2535 & 0.2603 & -12.7551 & 63445 & 0.0000 \\
\hline Music(1=Yes) & 37756 & 0.2399 & 0.4270 & 0.2356 & 0.2442 & 25691 & 0.1483 & 0.3554 & 0.1440 & 0.1527 & 63447 & 0.2028 & 0.4021 & 0.1997 & 0.2060 & 28.3340 & 63445 & 0.0000 \\
\hline Non-Arts/Non-Humanities(1=Yes) & 37756 & 0.0197 & 0.1391 & 0.0183 & 0.0211 & 25691 & 0.0406 & 0.1975 & 0.0382 & 0.0431 & 63447 & 0.0282 & 0.1655 & 0.0269 & 0.0295 & -15.6446 & 63445 & 0.0000 \\
\hline Opera/Musical Theatre $(1=$ Yes $)$ & 37756 & 0.0302 & 0.1712 & 0.0285 & 0.0319 & 25691 & 0.0370 & 0.1888 & 0.0347 & 0.0393 & 63447 & 0.0330 & 0.1786 & 0.0316 & 0.0344 & -4.7069 & 63445 & 0.0000 \\
\hline Photography(1=Yes) & 37756 & 0.0032 & 0.0561 & 0.0026 & 0.0037 & 25691 & 0.0040 & 0.0629 & 0.0032 & 0.0047 & 63447 & 0.0035 & 0.0589 & 0.0030 & 0.0039 & -1.7177 & 63445 & 0.0859 \\
\hline Theatre $(1=$ Yes $)$ & 37756 & 0.1510 & 0.3580 & 0.1474 & 0.1546 & 25691 & 0.1606 & 0.3671 & 0.1561 & 0.1651 & 63447 & 0.1549 & 0.3618 & 0.1521 & 0.1577 & -3.2697 & 63445 & 0.0000 \\
\hline Visual $\operatorname{Arts}(1=Y e s)$ & 37756 & 0.0766 & 0.2660 & 0.0739 & 0.0793 & 25691 & 0.1041 & 0.3054 & 0.1003 & 0.1078 & 63447 & 0.0877 & 0.2829 & 0.0855 & 0.0899 & -12.0268 & 63445 & 0.0000 \\
\hline
\end{tabular}

